\title{
Návrhy zákonů v meziresortním připomínkovém řízení: zásadní fáze legislativního procesu, nebo přehlídka malicherných podnětů?*
}

\author{
Bills in Inter-ministerial Consultation Procedure: \\ Key Phase of the the Legislative Process \\ or Moment for Opportunity for Trivial Comments?
}

\author{
Robert Zbíral ${ }^{* *}$
}

\begin{abstract}
Abstrakt
Kvalita českého legislativního procesu a jeho výstupü je všeobecnè hodnocena jako tragická. Přes tato konsenzuálni turzeni toho o radě duiležitých fází prípravy zákonư víme velmi málo. Jedním z takových černých mist je meziresortni pripominkové rízeni, sloužici jako unikátni príležitost ke pripominkováni návrhů zákonu. Tento článek se snaži uvedenou mezeru v poznáni zaplnit a nabizí nejen dủkladný rozbor formálnich základu mez̧iresortního pripominkového rizuení, ale predevšim detailni empirickou analyzu prüběbu a výsledkü pripomínkových rízeni 623 návrbů zákonů predloženými mezi lety 2010 až 2016. Poznatky z analýzy dokazuji, že predevšm ministerstva se účastni pripomínkováni velmi ak.tivně (byt’ v rozdilné míre) a nástroj značně ovlivñuje podobu návrhü zákonü. Spíse než prịimat radikální z.mèny meziresortniho rízeni by proto bylo vbodné omezit rüzné výjimky udělované v procesu a ponechat na pripominkováni vice času.
\end{abstract}

Klíčová slova

Príprava zákonuं; vláda; byrokracie; meziresortni pripominkové rízeni; kvalita zákonuं; empirická analyza.

\section{Abstract}

Quality of both Czech legislative process and its outputs are generally viewed as tragic. Yet despite this consensual evaluation, we still know quite little even about important phases of law-making. One of these black spots is inter-ministerial consultation procedure (ICS) that serves as unique instrument for consultation of bills. This article seeks to fill the stated knowledge-gap and offers not only detailed review of formal framework of ICS, but mainly detailed empirical analysis of its course and results based on the data from 623 bills consulted between 2010 and 2016. Findings from the analysis suggest that mainly ministries participate in the ICS very actively (although to different degree) and the instrument

\footnotetext{
* Článek vznikl v rámci řešení grantu Grantové agentury ČR č. 17-03806S (Odhalování temného koutu legislativního procesu: Př́prava návrhů zákonů exekutivou). Za podporu vřele děkuji.

** Doc. JUDr. PhDr. Robert Zbíral, Ph.D., Katedra ústavního práva a politologie, Právnická fakulta, Masarykova univerzita, Brno / Department of Constitutional Law and Political Science, Faculty of Law, Masaryk University, Brno, Czech Republic / E-mail: Robert.Zbiral@law.muni.cz / Research ID: 55347048200
} 
significantly affects the content of bills. Therefore rather than adoption of profound changes to the process, it is recommended to constraint the frequent exceptions awarded within the ICS and prolong time dedicated to consultations.

\section{Keywords}

Law-Making; Executive; Bureacracy; Interministerial Consultation (Comment) Procedure; Quality of Laws; Empirical Analysis.

\section{Úvod}

Nechvalně proslulá „poučka“ o právnickém stavu uvádí, že na jednu věc mají dva právníci obvykle (nejméně) tři názory. Dovolím si nesouhlasit. Každá žijící osoba, která o právo byt' jen zavadila, se totiž shodne na minimálně jedné záležitosti: tragické kvalitě české legislativy. Není třeba vyplňovat stránky nekonečným množstvím citací takových názorů, daný konsenzus dostatečně doloží odkazy na rozhovory s předsedy všech českých vrcholných soudů. ${ }^{1}$ Mnozí z kritiků zároveň identifikují široké spektrum důvodů, které za tvrzenou katastrofální situaci stojí. K nejčastěji zmiňovaným př́íčinám patří nedostatky $\mathrm{v}$ procesu přijímání legislativních předpisů. Bylo by opět nošením dříví do lesa citovat zde judikaturu Ústavního soudu, která se proti vybraným neblahým trendům vymezovala, z akademických polemik postačí zmínit již téměř 15 let starý „legendární “ prŕíspěvek Tomáše Richtera. ${ }^{2}$

Poznámka, že k možnosti cokoliv kritizovat je nejdříve nutné onu věc perfektně poznat, zavání banalitou. Je ale v tomto směru legitimní se ptát, zda pocit’ovanou důležitost problematiky normotvorby reflektuje v českém prostředí též výzkumné snažení odborné právní (případně politologické) obce, pomocí jejíchž výstupů ony poznatky můžeme získávat. Marian Kokeš před několika lety skeptický pohled na tehdejší stav výzkumu včlenil přímo do názvu svého článku. ${ }^{3}$ Osobně situaci i ve srovnání s podobně velkými státy nevidím tak černě. Díky dlouhodobému působení řady autorů, čistě namátkou např́iklad Jana Filipa, Jana Kysely, Petra Mlsny, Josefa Vedrala, Markéty Whelanové nebo Jana Wintra, toho víme o tvorbě práva a legislativním procesu v ČR relativně hodně. $\mathrm{K}$ „formujícím“ publikacím můžeme přiřadit i přes starší datum vydání dvě monografie

1 Srv. rozhovory s P. Rychetským (MAZANCOVÁ, Hana a Lukáš PRCHAL. Mynář dostal lekci, Ovčáčkovy urážky nemají v civilizovaném světě obdoby. Překvapuje mě, co Zeman snáší a podporuje, ř́ká Rychetský. Deník N [online]. 31. 1. 2019. Dostupné z: https://1url.cz/nzx7e), J. Baxou (MALECKÝ, Robert. Zákony dnes píší děti. Ceská justice [online]. 21. 1. 2014,. Dostupné z: https://1url.cz/kzx7W) a P. Šámalem (JANUŠ, Jan. Šéf Nejvyššího soudu Šámal: Zákony jsou džungle, nikdo je nezná všechny. Je to kritické. info.cz [online]. 28. 1. 2019. Dostupné z: https://1url.cz/Zzx7w).

2 RICHTER, Tomáš. Jak (ne)pomoci legislativnímu procesu. Právní roz̧bledy, 2007, č. 3.

3 KOKEŠ, Marian. Teorie zákonodárství aneb pokus čelit nezájmu právní teorie a politologie o legislativní tvorbu práva v ČR. Správní právo, 2016, č. 1. 
editované Alešem Gerlochem a Janem Kyselou ${ }^{4}$ nebo komplexního praktického průvodce legislativním procesem z roku 2011.5 I článků byla vydána celá raada, nakonec časopis Správní právo disponuje dokonce speciální legislativní prŕlohou. Vývoj poznání samozrejmě neustále pokračuje. Zmíněný M. Kokeš, snad veden úsilím napravit jím poukazovaný deficit, sám přidal ruce $\mathrm{k}$ dílu a sepsal a aktuálně vydal rozsáhlou monografii věnující se př́ípravě zákonů v ČR. ${ }^{6}$

Přesto po mém soudu výzkum české tvorby práva stále ukrývá dvě slabá místa. První z nich souvisí s převládajícím přístupem k poznávání problematiky, který odpovídá konceptu „teorie a praxe“ zmíněné v titulech řady dosud citovaných knih. Teorii se věnují tradičně akademici, používající klasické právní metody: rozebírají právní předpisy, judikaturu, přinášejí myšlenky z prací zahraničních autorů a hodnotí externě činnost legislativních orgánů a jejich výstupy. Praktické fungování představují osoby podílející se aktivně na tvorbě práva ve veřejné správě: ${ }^{7}$ ty sdílejí své zkušenosti, vykládají interní instrukce či poukazují na konkrétní př́klady. ${ }^{8} \mathrm{Jak}$ již bylo řečeno, tato kombinace př́ístupů dovoluje odhalit o tvorbě práva mnohé. Bohužel jeden rozměr neposkytne - zhodnocení situace na základě objektivně ověritelných dat. ${ }^{9}$ Legislativní proces a jeho výstupy se skládají z mnoha kroků a prvků, které lze kvantitativně popsat a tím určitou věc (když nic jiného) důkladně prozkoumat. Jestliže je cílem někoho analyzovat vliv Senátu při schvalování návrhů zákonů, je samožrejmě zcela legitimní se zamýšlet nad rolí horní komory nebo abstraktně rozebírat jí Ústavou či jednacím řádem stanovené varianty postupu, stejně tak prospěšné bude si přečíst názory reálného účastníka (senátora či úředníka) vyjednávacích procesů. Tyto informace ale budou pouze dílčí bez doplnění celkového obrazu, tedy kvantifikace toho, jak Senát fakticky využívá své legislativní pravomoci. ${ }^{10}$ Pokud uvedu jiný př́lklad: je na místě kritizovat neblahé užívání př́lepků nebo komplexních pozměňovacích návrhů, k tomu je ale také užitečné seznat, nakolik rozšířená daná praxe vưbec je. ${ }^{11}$

4 GERLOCH, Aleš a Jan KYSELA (eds.). Tvorba práva v Ceské republice po vstupu do Evropské unie. Praha: ASPI, 2007; GERLOCH, Aleš a kol. Teorie a praxe tvorby legislativy. Praha: ASPI, 2008.

5 BOHADLO, David a kol. Legislativni proces (teorie a praxe). Praha: Ministerstvo vnitra, 2011.

6 KOKEŠ, Marian. Temná zákoutí legislativního procesu: príprava vládních návrhů qákonů v ČR. Praha: Leges, 2021.

7 Je pravdou, že u mnoha jedinců dochází k propojení obou světů a většinoví praktici se věnují akademické činnosti a naopak.

8 Tým kolem Martina Škopa se nově věnuje systematickému výzkumu postojů praktiků při tvorbě práva, viz ŠKOP, Martin a kol. Tvorba práva - empirické studie. Brno: Masarykova univerzita, 2019.

9 V jiné souvislosti jsem se již tuto myšlenku snažil podrobněji vysvětlit v ZBÍRAL, Robert. Volání po posílení empirie: Jak (ne)měnit českou Ústavu. Jurisprudence, 2015, č. 4, s. 10-15.

10 Takto aktivity Senátu efektivně popisuje HRUŠKA, Jan. Role Senátu v českém politickém systému pohledem kvantitativní analýzy. In: KYSELA, Jan (ed.). 20 let Senátu Parlamentu Céské republiky v souvislostech. Praha, Leges, 2016, s. 113-127.

11 „Rozšířenost praxe“ se nerovná popisu jednoho či několika náhodně vybraných anekdotických př́íkladů. 
Přes jisté pokroky při shromažd’ování a analýze dat o tvorbě práva a právních předpisech obecně ${ }^{12}$ existuje v ČR v této oblasti stále množství bílých míst k zaplnění.

Za druhou slabinu českého výzkumu tvorby práva považuji jistou tematickou mezerovitost. O určitých institutech či subjektech zákonodárného procesu toho jednoduše bylo napsáno relativně málo či nic. Mnozí pozorovatelé české normotvorby např́klad poukazují na negativní vliv sněmovního kutilství na podobu legislativy. Nejenže ale chybí konkrétnější data o reálné míře vlivu Sněmovny (viz předchozí odstavec), nevím ani o žádném odborném textu, který by systematicky a do hloubky zkoumal naprríklad legislativní roli výborů, které jsou přitom klíčovými aktéry legislativního procesu ve Sněmovně i Senátu. ${ }^{13}$ Ještě větší znalostní deficit než v parlamentní fázi pak dle mého panuje ve stadiu exekutivní př́pravy návrhů zákonů. Přestože role vlády v legislativním procesu je v ČR oproti tradičním parlamentním demokraciím ${ }^{14}$ komparativně slabší, ${ }^{15}$ nenî pochyb, že stále zastává úlohu garanta vývoje legislativy a z ústavního i zákonného postavení odpovídá za př́pravu a prosazení rozhodujících právních předpisů. Exekutivní fáze př́pravy návrhů zákonů má tudíž pro tvorbu práva zásadní důležitost.

Jednou z nezbytných součástí exekutivní fáze normotvorby je široká konzultace připravovaných návrhů, sloužící k zvýšení odpovědnosti veřejné správy a zajištění zásad dobré správy a vládnutí. ${ }^{16} \mathrm{~V}$ českém prostředí jsou návrhy právních předpisů připravovaných v rámci exekutivy předkládány do vnějšího připomínkového řízení (též tzv. meziresortnî připomínkové řízení, dále jen jako „MPŘ ‘). Zatímco př́iprava návrhu může být v rukou omezené skupiny osob (výjimečně i jedné), poté je potřebné zohlednit zájmy ostatních subjektů, včetně vzájemné široké koordinace přístupů. Jeden z mála odborníků věnující pozornost MPŘ jej označuje za „nejkomplexnèjš́ kontrolni mechanismus celé exekutivní fáze normotvorby [...] kde je predkeládaný návrh posuzován nejzevrubněji“" ${ }^{17}$ dle jiného autora

12 Nejvíce údajů je zpřístupněno o činnosti Poslanecké sněmovny (např. KOLÁŘ, Petr a kol. Parlament České republiky. Praha: Leges, 2013; LINEK, Lukáš a Zdenka MANSFELDOVÁ (eds.). Ceský parlament ve drubé dekádě demokratického vývoje. Praha: Sociologický ústav, 2009); o legislativě částečně i CVRČEK, František a kol. Legislativa. Teoretická východiska a problémy. Plzeň: Aleš Čeněk, 2017; zejména k evropeizaci českého právního řádu a legislativního procesu několik příspěvků napsala i má maličkost (za všechny ZBÍRAL, Robert. Evropeizace českých zákonů 1998-2013: Empirické údaje o míre vlivu práva EU a dopadech na legislativní proces. Casopis pro právní védu a praxi, 2015, č. 3, s. 229-240).

$13 \mathrm{~V}$ zahraničí přitom problematika parlamentních výborů tvoří samostatný vědecký obor s desítkami výstupů, srov. přehled v MARTIN, Shane. Committees. In: MARTIN, Shane a kol. (eds.). The Oxford Handbook of Legislative Studies, Oxford: Oxford University Press, 2014, s. 352-370.

14 Viz příspěvky v RASCH, Bjorn a George TSEBELIS (eds.). The Role of Governments in Legislative Agenda Setting. London: Routledge, 2011.

15 Podrobně k slabosti české exekutivy KYSELA, Jan a Marian KOKEŠ. Role vlády v procesu právotvorby v České republice se zřetelem k efektivitě vládnutí. Správníprávo-Legislativní príloha, 2018, č. 1, s. 40-58.

16 Obecně RADAELLI, Claudio. Regulating rule-making via impact assessment. Governance, 2010, č. 1, s. 89-108.

17 BARTOŠEK, Jan. Byrokraticko-exekutivní fáze zákonodárného procesu. In: MOLEK, Pavel a kol. (eds.). Dny práva 2014. Brno: Masarykova univerzita, 2015, s. 30-31. 
MPŘ má za cíl „dosábnout všestranné úrovně a kvality právního predpisu“ ${ }^{18}$ Přes tato velkolepá prohlášení dosud průběh a dopad MPŘ patři k málo prozkoumaným koutům české tvorby práva.

Cílem tohoto př́spěvku je podrobný rozbor průběhu a dopadů MPŘ. Kromě popisu formální úpravy a praxe MP̌̌ článek předmětný cíl naplňuje prostřednictvím zpracování a analýzy rozsáhlého souboru dat obsahujícího rozličné údaje o průběhu MPŘ pro všechny návrhy zákonů mezi lety 2010 až 2016. V tomto ohledu mám ambici „,zabít dvě mouchy jednou ranou“, článek se pokouší přispět k překlenutí obou výše definovaných slabých míst českého výzkumu tvorby práva. Je vhodné zdůraznit, že použitý empirický přístup trpí vrozenými omezeními. Dovoluje dosti výstižně a objektivně odhalit, co je v datech obsaženo, není však schopen posoudit právníky mnohdy očekávaná zhodnocení „kvality“ (k tomu viz níže). Zároveň MPŘ analyzuji ve stávající formě a nepouštím se na tenký led normativního uvažování, např́klad ve stylu, zda by nemohl nebo neměl fungovat úplně jiný model připomínkování. Možných př́istupů k němu je totiž celá řada (srov. dále) a volby mezi nimi ponechám povolanějším. ${ }^{19}$

Článek je rozdělen na následující části. První kapitola pro srovnání krátce představuje podobu připomínkových řízení v geograficky a právně ČR blízkým státům. Další sekce detailně analyzuje formální rámec MPŘ a jeho praktické fungování. Následně jsou již prezentována data o celkovém průběhu MPŘ a úloze jednotlivých subjektů do něj zapojených, zvláště pak ministerstev. Předposlední část příspěvku přibližuje dopady MPŘ na podobu předkládaných návrhů zákonů. Závěr stručně opakuje hlavní zjištění a pokouší se na jejich základě formulovat doporučení ke zlepšení situace.

\section{Připomínková řízení v zahraničí: stručný exkurz}

Doyen politologie Giovanni Sartori obhajoval tezi, že „[...] každý kdo zná použe jednu zemi, nezná ve skutečnosti žádnou. "20 Před rozborem české situace tak může být užitečné krátce představit formu a praxi připomínkových řízení v jiných státech. Lze se důvodně domnívat, že nějaký způsob připomínkování vládních návrhů zákonů probíhá v naprosté většině demokratických zemí světa. Bohužel však narážíme na nedostatek, či spíše jednostranné zaměření zdrojů, které se problematice věnují. Pozornost je totiž věnována především konzultacím návrhů právních předpisů s veřejnostíi ${ }^{21}$ či obecně vlivu zájmo-

18 ŠÍN, Zbyněk. Tvorba práva: pravidla, metodika, technika. 2. vyd. Praha: C. H. Beck, 2009, s. 92.

19 Viz RICHTER, 2007, op. cit., který by MPŘ zařadil až na konec exekutivní fáze normotvorby.

20 SARTORI, Giovanni. Compare Why and How. Comparing, Miscomparing and the Comparative Method. In: DOGAN, Matei a Ali KAZANCIGIL (eds.). Comparing Nations: Concepts, Strategies, Substance. Oxford: Blackwell, 1994, s. 16.

21 Za všechny JOHNS, Melissa a Valentina SALTANE. Citizen engagement in rule-making - Evidence on regulatory practices in 185 countries. Washington: World Bank Group, 2016; prrípadně MILANO, Flavia a Ulises PALLARES. Public Consultations: Step by Step. Washington: Inter-American Development Bank, 2020. 
vých skupin na legislativní proces, ${ }^{22}$ zatímco způsob zapojení a vliv subjektů veřejné moci odborné texty víceméně přehlížejí. Níže poskytuji základní informace o připomínkových řízeních v středoevropských zemích, které jsou ČR právní i politickou tradicí nejbližší; analýza je dále doplněna o Spojené království jako „nejvíce odlišný př́pad“.

V Německu drží při projednávání návrhů zákonů klíčovou pozici ministerstva vnitra a spravedlnosti, které posuzují soulad návrhů s organizací veřejné správy a ústavními kautelami (srov. \46 jednacího řádu federálních ministerstev). ${ }^{23}$ Poté následuje připomínkové řízení s ostatními subjekty včetně zbylých ministerstev, lhůta pro podávání připomínek je minimálně čtyři týdny, ale na žádost jiného ministerstva může být až zdvojnásobena, ve výjimečných př́padech naopak zkrácena na dny (srov. \50 citovaného jednacího řádu). V praxi je připomínkové řízení méně formalizováno než v ČR, vypořádání probíhá zejména ústně na poradách a provádějí jej úředníci, u sporných záležitostî ovšem pod bedlivým dohledem nadřízených včetně politického vedení ministerstev. ${ }^{24}$ Podobné rysy vykazuje připomínkové řízení v Rakousku, také zde je na předkládajícím subjektu, koho k prripomínkování pozve. Zvláštní privilegovanou pozici nicméně zaujímají s ohledem na tradiční korporativistický model vládnutí hospodářští a sociální partneři, zemské vlády a předběžně konzultován je též federální parlament. Lhůta pro připomínkování je neformálně stanovena na šest týdnů, v odůvodněných případech ji lze zkrátit i prodloužit. Vypořádání připomínek je zcela $\mathrm{v}$ diskreci ministerstva odpovědného za návrh. ${ }^{25}$

Mad’arský model vykazuje naopak centralizační tendence. Návrh zákona musí nejdříve ministerstvu schválit speciální útvar premiéra a ministerstvo financí, teprve poté vstupuje do připomínkového řízení, které začíná ve stejný okamžik jako veřejné konzultace. K prripomínkování je často stanovena extrémně krátká lhůta klidně v řádech dnů i hodin, zasílání připomínek probíhá přes emaily. Za takových podmínek nepřekvapí, že dopad připomínkových řízení je mizivý a omezuje se nejčastěji na formálně legislativní komentáře. ${ }^{26}$ Polské řešení připomínkového řízení také kombinuje meziresortní a veřejnou konzultaci. Právní úprava v jednacím řádu vlády je velmi podrobná (srov. \31 až 52), ${ }^{27}$ přesto dává navrhujícímu subjektu poměrně velký prostor pro diskreci co do určení

22 Za všechny DÜR, Andreas a Gemma MATEO. Insiders versus Outsiders: Interest Group Politics in Multilevel Europe. Oxford: Oxford University Press, 2016.

23 Gemeinsame Geschäftsordnung der Bundesministerien, verze 30. červenec 2020. Dostupné z: https://1url.cz/Ozxeu

24 Podrobněji MAASSEN, Hans-Georg. Gesetzesinitiativen der Bundesregiurung. In: KLUTH, Winfried a Günter KRINGS (eds.). Gesetrgebung. Heidelberg: C.F. Müller, 2014, s. 207-212.

25 Více MIKLIN, Eric. Austria. In: ZBÍRAL, Robert (ed.). The Cradle of Laws: Drafting and Negotiating Bills within the Executives in Central Europe. Oxford: Hart/Nomos, 2020, s. 39-42.

26 Srv. SZÁBO, Zolt. Hungary. In: ZBÍRAL, 2020, op. cit., s. 95-96.

27 Regulamin pracy Rady Ministrów (Uchwała Nr 190 Rady Ministrów z dnia 29 października 2013), verze 10. února 2021. Dostupné z: https://www.lexlege.pl/regulamin-pracy-rady-ministrow/ 
připomínkových míst a lhůty pro podání připomínek (standardně 21 dnů, často zkrácená). Ministerstvo má připomínky vypořádat. Ty, na kterých s připomínkujícími místy nenašlo shodu, sepíše do zprávy a předá na vyšší úroveň k vyřešení, konkrétně jsou postoupeny tzv. Stálému ministerskému výboru. Výhodou připomínkového procesu je jeho transparentnost, ${ }^{28} \mathrm{~s}$ výsledky však velká spokojenost v literatuře nepanuje, problémem je zvláště krátká lhůta většiny připomínkových řízení a nejasná odpovědnost zapojených institucí. ${ }^{29}$

Slovenský systém připomínkového řízení nezapře společné historické kořeny s českým. Základní parametry procesu jsou ovšem na rozdíl od ČR vymezeny zákonem, ${ }^{30}$ přičemž dle základního pravidla každý návrh zákona musí po svém zveřejnění na portálu SlovLex $^{31}$ projít připomínkovým řízením. Podrobnosti stanoví čl. 13 až 15 legislativních pravidel slovenské vlády. ${ }^{32}$ Výčet povinně předkladatelem oslovovaných subjektů je relativně široký, lhůta pro podání připomínek se stanoví na alespoň 15 dnů, zkrácení na nejméně sedm dnů se připouští výhradně za mimořádných okolností. Zajímavě jsou upraveny zásadní připomínky, může je totiž uplatnit pouze ministr či státní tajemník a formálně jde o takové připomínky, u kterých $\mathrm{v}$ př́padě jejich neakceptování předkladatelem návrhu bude uplatňující ministr pravděpodobně hlasovat na vládě proti přijetí předlohy. Předkladatel návrhu se snaží připomínky vypořádat a vyřešit neshody, přetrvávající rozpory posuzuje vláda. Připomínkové řízení je specifické povinným zapojením veřejnosti. Jestliže uplatnilo tzv. hromadnou připomínku více než 500 osob a předkladatel ji nevyhověl, je třeba konat rozporové rrízení též se zástupcem veřejnosti. Jelikož všechny připomínky se podávají elektronicky v rámci portálu Slov-Lex, lze je jednoduše procházet. Od července 2016 bylo podáno ke všem materiálům přes 162 tisíc připomínek (z toho 48 tisíc bylo zásadních a 1200 hromadných připomínek veřejnosti). Bohužel třídění dle druhu materiálu zdá se nefunguje a nelze bez procházení všech jednotlivých prrípadů ani odhalit výsledky vypořádání připomínek. Dopady připomínkového řízení na Slovensku je poměrně obtížné zhodnotit, literatura mu v podstatě nevěnuje pozornost. Drobné

28 Všechny materiály včetně připomínek jsou př́istupné z: https://legislacja.rcl.gov.pl/

29 K tomu BORSKI, Maciej. Przygotowywanie projektów ustaw przez Rade Ministrów - Wybrane zagadnienia. Roczniki Administracji i Prawa, 2018, č. 2, s. 39-56; SOKOLOWSKI, Jacek. Poland. In: ZBÍRAL, 2020, op. cit., s. 112-115.

30 Srv. \10 zákona č. 400/2015 Sb., Zákon o tvorbe právnych predpisov a o Zbierke zákonov Slovenskej republiky a o zmene a doplnení niektorých zákonov.

31 Dostupné z: https://www.slov-lex.sk/domov

32 Legislatívne pravidlá vlády Slovenskej republiky, znění platné od 15. července 2020. Dostupné z: https:/ / www.vlada.gov.sk/data/files/7912_uplne-znenie-legpravvladysr-v-zneni-uzn-vlsr-z-15-jula-2020-c-466. pdf 
výjimky tak činí dosti popisně, nebo jako v př́padě článku posuzujícího vliv účasti veřejnosti na připomínkování jsou pozitivní dopady pouze normativně očekávány. ${ }^{33}$

Oproti řadě kontinentálních zemí je ve Spojeném království proces př́pravy návrhů zákonů značně formalizovaný a předpokládá dlouhodobé úsilí, obyčejně započaté rozsáhlými konzultacemi s dotčenými aktéry a vydáním různých Zelených či Bílých knih. Paradoxně samotná možnost připomínkování návrhů ostatními subjekty veřejné správy ${ }^{34}$ je výjimkou z obecného rámce a visí v zásadě ve vzduchoprázdnu. Pokud navrhovaná legislativa ovlivňuje působnost jiných ministerstev nebo správních úřadů, tyto mají být samozřejmě konzultovány. ${ }^{35}$ Neexistuje ale žádný předpis, určující kdo přesně a kdy se má do připomínkování zapojit. Obecně připomínkování spadá do gesce odboru Parlamentních činností a legislativy při Úřadu vlády a oproti situaci v systémech s koaličními vládami je patrné, že př́ípravná činnost je koordinovanější a ministerstva se mnohem více podřizují ve prospěch vlády jako celku. ${ }^{36}$

Poskytnutý přehled přináší zajímavé poznatky, na druhou stranu ukazuje na výrazné odlišnosti řešení i mezi geograficky a právně „příbuznými“ státy střední Evropy. Většina zemí připomínkové řízení formalizuje alespoň na úrovni jednacích řádů vlád/ministerstev, míra podrobnosti už se liší. Rakousko a Německo vymezují jen základy a též v praxi připomínkové řízení funguje spíše zvykově a v pozadí. Oproti tomu v postkomunistickým státech s výjimkou Mad’arska je úprava detailnější se snahou o stanovení jasnějších pravidel včetně vyšší transparentnosti, jenže typicky třeba lhůty k připomínkování jako klíčový parametr řízení jsou nastaveny restriktivněji a častěji se též zkracují. Přestože komparativní zhodnocení efektivity připomínkových řízení není pro rozdílnost úprav a nedostatek dat proveditelné, lze úspěšně pochybovat o nadřazenosti druhého („postkomunistického“ nebo tzv. formalizovaného) modelu. Na Slovensku, v Mad’arsku a Polsku je do připomínkového řízení oficiálně zapojena rovněž veřejnost. Vzhledem ke krátkým lhůtám a obecné náročnosti komentování paragrafovaných znění návrhů zákonů by bylo až naivní očekávat, že by veřejnost mohla nějak významně podobu návrhů ovlivnit. Zájmy „,veřejnosti“ mohou poté lépe zastoupit sběrné subjekty typu sociálních partnerů, které mají v některých státech (např́iklad Rakousko, ale též Polsko) při připomínkování tradičně privilegované postavení.

33 Srv. FARKAŠOVÁ, Simona. Občianska participácia v slovenskom legislatívnom procese. Mladá veda, 2020 , č. 1 , s. 89.

34 Výjimkou jsou devolvované úŕady (vlády Skotska, Walesu a Severního Irska).

35 ZANDER, Michael. The Law-making Process. Oxford: Hart Publishing, 2015, s. 10.

36 Srv. také instrukce v Cabinet Office. Guide to Making Legislation, verze červenec 2017, zejména s. 54-55. Dostupné z: https://1url.cz/7zxen 


\section{Formální rámec meziresortního připomínkového řízení k návrhům zákonů v České republice a nástin jeho praktického fungování}

Z historického hlediska má připomínkové řízení $\mathrm{k}$ návrhům právních předpisů na českém území dlouhou tradici. První instrukce pro vytváření legislativy po vzniku Československa sice nejprve proces př́ipravy vůbec neupravovaly, ale to se změnilo již v polovině 30. let minulého století. ${ }^{37}$ Legislativní pravidla vlády z roku 1949 pak zaváděla dokonce několikastupňový připomínkový proces. Nejprve se projednávaly celkový legislativní plán na pololetí a tzv. zásady (předběžný rámec jednotlivých úprav), teprve poté se konalo „standardni““ připomínkové řízení, jehož cílem bylo, aby „osnova a divvodová zpráva plné vyjadrovaly politický smysl stanovených zásad a aby jejich znèní bylo po v̌́ech stránkách zdokonaleno". Lhưta pro zaslání připomínek byla 14 dnů a projednávaly se ústně. ${ }^{38}$ Připomínkové řízení bylo upraveno i ve všech dalších legislativních pravidlech vlády. ${ }^{39}$

Aktuální formální podoba MPŘ je vymezena v nyní platných legislativních pravidlech vlády (dále jen jako „LPV“). ${ }^{40}$ Je třeba upozornit, že se nejedná o jedinou prríležitost k připomínkování v exekutivní fázi normotvorby. Předkladatel návrhu totiž ještě před jeho zpracováním má dle čl. 2 odst. 1 LPV ve vymezených případech provést širokou analýzu hodnocení skutkového a právního stavu. Při ní postupuje na základě Obecných zásad pro hodnocení dopadů regulace (RIA), ${ }^{41}$ dle kterých jsou jedním ze zdrojů dat pro analýzu rovněž konzultace. Citovaný předpis ovšem výslovně ponechává délku a formu konzultací na předkladateli, ${ }^{42}$ a to včetně stanovení okruhu konzultujících subjektů. ${ }^{43} \mathrm{O}$ kvantitě a kvalitě konzultací v rámci RIA si netroufám spekulovat, obecně má proces hodnocení dopadů přes jistá zlepšení v posledních letech k dokonalosti daleko. ${ }^{44}$ Předkladatel dále standardně posílá pracovní verzi návrhu zákona do vnitřního připomínkového řízení

37 BOHADLO a kol., 2011, op. cit., s. 283.

$38 \mathrm{~K}$ tomu BLÁHOVÁ, Ivana. Legislativní pravidla v době tzv. právnické dvouletky. In: VOJÁČEK, Ladislav a Jaromír TAUCHEN (eds.). III. česko-slovenské právnébistorické setkéni doktorandi a postdoktorandü. Brno: Masarykova univerzita, 2015, s. 19-22.

39 Znění všech minulých legislativních pravidel vlády je k dispozici v ŠíN, Zbyněk. Legislativní pravidla I-III. Olomouc: Univerzita Palackého, 2006.

40 Legislativní pravidla vlády schválená usnesením vlády č. 188 ze dne 19. března 1998, aktuální znění dostupné z: https:/ / 1url.cz/yzAwk; K právnímu charakteru LPV včetně relevantní judikatury Ústavního soudu více KOKEŠ, 2021, op. cit., s. 222-225.

41 Aktuální verze účinná od 3. února 2016 je dostupná z: https://1url.cz/JzAwV

42 Pro konzultace nicméně existuje doporučený postup vymezený v metodice a manuálu. Dostupné z: https://ria.vlada.cz/ria/konzultace/

43 Zde je možné využít databázi připomínkových míst Datako (Dostupné z: https://kormoran.odok.cz/ ODOK/datako-dir.nsf), ta nicméně zjevně není př́liš reprezentativní.

44 Srv. ZBÍRAL, Robert. Legislation in the Czech Republic. In: XANTHAKI, Helen a Ulrich KARPEN (eds.). Legislation in Europe: A Country by Country Guide. Oxford: Hart, 2020, s. 133-134; také KOKEŠ, 2021, op. cit., s. 242-254. 
(např. v rámci ministerstva). Není veřejné a jeho průběh a způsob zpracování výsledků je zcela $v$ gesci př́slušného subjektu. ${ }^{45}$

Ačkoliv se dále bude text věnovat pouze návrhům zákonů, MPŘ kromě nich (čl. 8 LPV) podléhají (v rámcově obdobné podobě) rovněž návrhy věcných záměrů zákonů (čl. 5 LPV), nařízení vlády (čl. 13 LPV) a vyhlášek (čl. 16 LPV). Pro dané druhy návrhủ předpisů je MPŘ povinné. Ve výjimečných př́padech může být konání MPŘ na návrh předkládajícího ministra vynecháno, souhlasit s tím musí předseda Legislativní rady vlády (čl. 76 LPV). Takový postup je nutné odůvodnit a přistupuje se k němu na rozdíl od zúžení MPŘ (viz níže) pouze mimořádně při neočekáváných událostech. Pravdou je, že v době pandemie Covid-19 byla výjimka z MPŘ udělována nepoměrně častěji a někdy dokonce jen ústně.

MPŘ návrhu zákona formálně začíná zveřejněním daného návrhu spolu se všemi vyžadovanými součástmi v elektronické knihovně eKLEP informačního systému ODok Úřadu vlády, ${ }^{46}$ ve stejnou chvíli musí být návrh zavěšen rovněž do veřejnosti přístupné verze elektronické knihovny (systém VeKLEP). ${ }^{47}$ Předkladatel zároveň určí lhůtu k podávání připomínek. Standardně činí 20 pracovních dnů, ale může být stanovena delší. V případě udělení již diskutované výjimky dle čl. 76 LPV lze lhưtu naopak zkrátit, ne však na méně než 5 pracovních dnů. Ve vymezené lhůtě musí připomínkové místo zvládnout veškeré úkony s připomínkováním spojené, tj. nastudování předlohy, prodiskutování a schválení formulovaných pozic $\mathrm{v}$ rámci pripomínkového místa a samotné vypracování prripomínek. Nepřekvapí tudíž, že naprostá většina připomínkových míst zasílá tradičně připomínky až v poslední den lhůty. ${ }^{48}$

Kromě lhůty předkladatel vytyčí rovněž okruh subjektů, které návrh zákona mají připomínkovat. Také v tomto př́padě základní rámec upravují LPV, konkrétně čl. 5 odst. 1 LPV obsahuje seznam tzv. povinných připomínkových míst. Ve srovnání s probíranými zeměmi jde o seznam velice rozsáhlý a zahrnující nejen různé subjekty veřejné správy a samosprávy, ale též zastř̌ešující organizace zastupující rozličné zájmy a od roku 2014 též zákonem zř́izené profesní komory. Od vydání LPV v roce 1998 se počet povinných připomínkových míst rozšíril několikanásobně. Tento pozitivní vývoj vedoucí k vyšší reprezentativnosti MPŘ má jeden háček. S výjimkou ministerstev a Odboru kompatibility Úřadu vlády je zapojení všech zbylých „povinných“ subjektů MPŘ podmíněno tím, že se návrh nějak dotýká jejich působnosti či zájmů. To je samozřejmě formulace dosti gumová a přestože si představuji jen obtížně, jak by se nějaký návrh zákona třeba krajů

45 K vnitřnímu připomínkovému řízení ŠRÁMEK, Aleš. Tvorba právních norem ve veréjné správě. Praha: Vodnář, 1995 , s. 63.

46 Dostupné z: https://apps.odok.cz/eklep

47 Dostupné z: https://apps.odok.cz/veklep

48 Mnohdy jsou připomínky v eKLEPu připomínkovým místem autorizovány i několik dnů po lhůtě, předkladatelé je přesto přijímají. 
nedotýkal vůbec, v praxi řada předkladatelů zjevně k „probírkám“ př́istupuje. Bohužel předkladatelé postupují různě třeba i návrh od návrhu, což zmíněnou ideu reprezentativnosti oslabuje. Okruh připomínkových míst lze zúžit také na základě výjimky dle čl. 76 LPV, pak je možné vyloučit i vybraná ministerstva. Občas k tomu předkladatelé přistupují, obyčejně to je spojeno se zkrácením lhưty k připomínkování.

Předkladatel má právo oslovit nad rámec výčtu povinných připomínkových míst také jakékoliv další subjekty dle svého uvážení. Tato možnost je dle mého názoru př́ležitostí i hrozbou zároveň. Na jednu stranu to dovoluje posílit inkluzivitu MPR a zapojit právnické či fyzické osoby se znalostí či zájmem o problematiku, na druhou stranu úplná diskrece při výběru umožňuje předkladateli zvolit si ta místa, která většinou jeho záměru konvenují. Okruh „privilegovaných“ subjektů proto obvykle vychází z historických vazeb či zkušeností předkladatele. ${ }^{49}$ Analýza těchto subjektů zapojených do MPŘ ${ }^{50}$ potvrzuje někdy dosti neuspořádaný a nelogický soubor připomínkových míst, který nenaplňuje požadavek širokého zastoupení různých zájmů a spíše indikuje poněkud utilitaristické vidění problematiky. Na rozdíl od jiných zemí střední Evropy MPŘ vůbec neupravuje účast veřejnosti. Teoreticky nikomu včetně jednotlivců není bráněno v zaslání připomínek na elektronickou adresu předkladatele zveřejněnou spolu s návrhem ve VeKLEPu, předkladatel ale $\mathrm{k}$ tomu veřejnost aktivně motivuje či upomíná jen výjimečně a tak není divu, že z hlediska míry zapojení veřejnosti do prrípravy legislativy je ČR v rámci EU řazena do nejnižší kategorie států. ${ }^{51}$

LPV nikde nevymezují obsah připomínek, požadují však jejich jednoznačnost a konkrétnost a odpovídající odůvodnění. Připomínky mají být děleny na obecné a k jednotlivým ustanovením. ${ }^{52}$ První kategorie vyjadřuje názory připomínkového místa na celý návrh či jeho část, často řeší systémové či koncepční otázky. Zde platí jednoduchá úměra: čím je pro připomínkové místo návrh překvapivější/novější, ${ }^{53}$ tím bývá počet a hloubka obecných připomínek vyšší. U druhé kategorie připomínek je zpravidla navrhována změna, odebrání či naopak přidání konkrétního ustanovení, úkolem připomínkového místa je vždy navrhnout novou formulaci ustanovení (čl. 5 odst. 6 LPV). Z hlediska rozsahu v tomto prrípadě může jít o připomínky sahající od upomínky na chybějící čárku po velmi komplexní úpravy předloženého znění určitého ustanovení.

49 Srv. rozhovor s úředníkem v ŠKOP a kol., op. cit., s. 186.

$50 \mathrm{~V}$ neveřejné části eKLEPu je možné zjistit, na jaké emailové adresy předkladatel návrh k připomínkování zaslal. Můj závěr je založen pouze na kontrole náhodného vzorku MPŘ.

51 THIJS, Nick a kol. A comparative overview of public administration characteristics and performance in EU28s. Brussels: European Commission, 2018, s. 32.

52 Připomínky nemusí směřovat pouze $\mathrm{k}$ textu návrhu zákona, ale též $\mathrm{k}$ doprovodným materiálům (důvodová zpráva, hodnocení dopadů regulace, návrhy prováděcích předpisů).

53 Např. proto, že nebyl předtím diskutován ve formě věcného záměru zákona či neformálních mechanismů. 
Druhou dělící linií je rozlišování mezi zásadními a doporučujícími připomínkami. Do první skupiny patři takové, která připomínkující místa „považuji za podstatné" (čl. 5 odst. 7 LPV). To věru není př́liš návodná nápověda pro definici takové připomínky. Označení připomínky za zásadní má ovšem především důležitý formální rozměr předkladatel je povinen ji vypořádat a pokud zastává $\mathrm{k}$ takové připomínce nesouhlasný postoj, ta se stává předmětem rozporu. Dle LPV jsou zásadní připomínky oprávněna podávat jen vybraná povinná připomínková místa, v praxi tak však činí všechna povinná připomínková místa a předkladatelé tento př́istup akceptují. Všechny připomínky neoznačené za zásadní jsou dle LPV brány jen jako návrhy a předkladatel $\mathrm{k}$ nim nemusí přihlîžet. Připomínková místa je proto obvykle doprovázejí termínem „doporučující připomínka“ (LPV termín nezná). Připomínkující subjekt často čelí dilematu, zda připomínce udělit status zásadní, nebo nikoliv. Kvưli efektivitě MPŘ by se s první kategoriî mělo šetřit pro materiálně nejvýznamnější námitky, na druhou stranu doporučující připomínky předkladatel začasté vypořádá spíše formálně a připomínková místa čelí riziku, že jejich připomínky zapadnou. ${ }^{54}$ Vyskytuje se ještě třetí skupina připomínek týkající se legislativně-technických požadavků (tzv. formální připomínky), obvykle namítající nedostatky v dodržování v LPV vymezených podmínek pro normotvorbu. Formální námitky nesmí být označovány za zásadní (čl. 5 odst. 7 LPV), není to ale přesné, nebot' i legislativně-technická chyba může mít závažné důsledky.

Po ukončení MP̌̌ předkladatel provádí vypořádání došlých připomínek. ${ }^{55}$ První krok procesu spočívá $\mathrm{v}$ analýze obdržených připomínek předkladatelem a jeho předběžném postoji k nim, nástrojem k tomu je tzv. vypořádací tabulka. Jestliže nejsou z analýzy patrné žádné kontroverze, je možné odeslat už toto zpracování připomínkovým místům k odsouhlasení a vypořádání uzavřít na dálku písemně. Většinou tomu tak není a zmíněný materiál je pouze podkladem pro předkladatelem svolanou vypořádací poradu. $\mathrm{Na}$ tomto jednání mohou zástupci připomínkových míst a předkladatele připomínky osobně prodiskutovat a odstranit pokud možno všechny neshody. Pokud není dosaženo konsenzu, lze konání porady opakovat či pořádat individuální schůzky. ${ }^{56}$ Předkladatel poté upraví vypořádací tabulku na základě výsledků jednání a odešle ji relevantním připomínkovým místům k závěrečnému schválení. Konečná podoba vypořádací tabulky

54 BOHADLO a kol., 2011, op. cit., s. 167.

55 Vypořádání se neprovádí, jestliže předkladatel na základě MPŘ návrh zákona stáhne (srov. detailně níže).

56 Vypořádací porady mohou být také konány separátně. Užitečné to může být především v následujících případech: 1) U rozsáhlých návrhů zákonů je vhodné konat porady zvlášt’ k tematicky užším celkům, 2) Jestliže některé připomínkové místo podalo velké množství připomínek, dává smysl s ním jednat samostatně, 3) Jestliže se rýsuje koordinovaný odpor více připomínkových míst proti návrhu, mưže být taktické subjekty pro jednání rozdělit; srov. také MAASEN, 2014, op. cit., s. 210. 
se zpřístupní v systému eKLEP spolu s předložením upraveného návrhu zákona vládě, tj. při vstupu návrhu do další fáze legislativního procesu. ${ }^{57}$

Způsob vypořádání v konečné podobě vypořádací tabulky dělí obdržené připomínky standardně do čtyř kategorií:

- Akceptováno: Připomínky, které předkladatel přijal a do návrhu je plně promítnul. Jestliže předkladatel souhlasil s obsahem připomínky, ale zvolil jiné řešení její implementace, používá se formulace „akceptováno jinak“.

- Vysvětleno: Jde o připomínky, které sice promítnuty nebyly, ale předkladatel s př́ipomínkovým místem připomínku probral a druhý ze subjektů na ni nadále netrvá.

- Neakceptováno: S implementací těchto připomínek předkladatel po vypořádání nesouhlasí a do návrhu je nepromítl. Odmítnuté připomínkové místo na připomínce sice trvá, ale nehodlá ji v dalším průběhu legislativního procesu formálně řešit.

- Neakceptováno/rozpor: S implementací těchto připomínek předkladatel po vypořádání nesouhlasí a do návrhu je nepromítl. Odmítnuté prripomínkové místo na připomínce ale trvá a hodlá ji dále řešit. Návrh vstupuje do vlády s rozporem a je na politickém vedení obou subjektů, aby se pokusilo o konsenzus. V př́padě nedohody a neustoupení předkladatele nebo připomínkového místa se rozpor předloží (spolu s návrhem zákona) k rozhodnutí vládě.

MP̌̌ návrhu zákona uvedenými úkony formálně končí a předkladatel návrh na základě výsledků MPŘ upraví. Jestliže by však výsledkem přepracování byla podstatná změna obsahu návrhu, čl. 5 odst. 12 LPV předvídá opakování MPŘ. Cílem je pravděpodobně zabránit situaci, kdy dojde na nátlak některého z připomínkových míst k zásadní změně návrhu, aniž by se k tomu ostatní připomínková místa mohla vyjádřit. Na druhou stranu není prríliš pravděpodobné, že by se něco podobného mohlo odehrát zcela bez povšimnutí, nebot' připomínková místa si do připomínek navzájem vidí, na vypořádací poradě se odhalí i záměry předkladatele a ten navíc musí postupovat tak, aby vyřešením námitky jedné nevznikl problém s jiným připomínkovým místem. Reálně je MPŘ k návrhu zákona opakováno extrémně výjimečně, ${ }^{58}$ návrhy čelící silnému odporu předkladatelé raději úplně opustí, u zvládnutelného počtu rozporů se snaží uspokojit odpůrce ve fázi projednávání návrhu vládou.

57 Specifický je postup vypořádání připomínek zaslaných subjekty mimo okruh povinných připomínkových míst. Závisí totiž zcela na uvážení předkladatele: někdy jsou tyto připomínky do vypořádací tabulky zařazeny, častěji však nikoliv. Náhodnost postupu samožrejmě odráží předchozí netransparentní průběh této části MPŘ (dané připomínky jsou zasílány emailem a zná je tudíž jen předkladatel) a nelze tudíž vyloučit, že předkladatel používá tyto připomínky instrumentálně k podpoře svého přístupu. Připomínky veřejnosti, pokud přijdou, jsou vypořádávány jen výjimečně a když už k tomu dojde, děje se tak spíše povrchně, srov. nap̌r. ,informaci“ o připomínkách veřejnosti k návrhu NOZ, dostupnou z: https://1url. $\mathrm{cz} / \mathrm{xzA} 2 \mathrm{~W}$

58 Jde hlavně o situaci, kdy neúspěšný návrh zákona je podáván znovu v novém volebním období. 


\section{Dostupnost a omezení shromážděných dat o meziresortním připomínkovém řízení a metodologie zpracování}

Představenou kostru v dalších částech doplním o „maso“ reálných dat z MPŘ. Spolu se svými kolegy ${ }^{59}$ jsem shromáždil údaje o všech návrzích zákonů, které byly předloženy do MPR za vlád Petra Nečase a Bohuslava Sobotky. ${ }^{60}$ Dle výsledků vyhledávání v eKLEPu se jednalo celkem o 623 návrhů, prakticky rovnoměrně rozdělených mezi obě vlády (Nečas 324, Sobotka 299). Kromě řady proměnných charakterizujících samotné návrhy (předkladatel, délka návrhu, vztah k právu EU atd.) šlo především o hodnoty vázané na průběh MPŘ. Ty byly zpracovány ručně z vypořádacích tabulek zveřejněných v eEKLEPu. Data z nevypořádaných MPR (82 návrhů) nejsou tudíž součástí analýzy. Cílem sběru dat bylo získat údaje o tom, kdo připomínky podával, jakého druhu a jakým způsobem na ně reagoval předkladatel.

Shromážděná data si nekladou nárok na dokonalost a úplnost. Výchozí problém tkví $\mathrm{v}$ již zmíněné diskreci, kterou předkladatelé mohou v MPŘ uplatnit. Jelikož je např́ḱlad na nich, která nepovinná prripomínková místa osloví a jestli jejich připomínky vypořádají, obsahuje dataset pouze informace o povinných připomínkových místech. Pro shromáždění dat z MPŘ je však mnohem větším problémem, že neexistuje ani žádný předepsaný způsob podoby vypořádací tabulky. Obvykle jde o extrémně rozsáhlý textový soubor v délce až stovek stran, který předkladatelé pojímají jinak. Zásadní rozdíly jsou ve formě zpracování: některé subjekty vytváří tabulku se systematicky číslovanými připomínkami, jiné „shlukuji““ připomínky dohromady a vypořádávají jich více najednou; řazení je prováděno dle připomínkových míst, ale výjimečně dle ustanovení předpisu; jiná je mnohdy terminologie (formální vs. doporučující připomínky). Odlišnosti jsou bohužel rovněž v obsahu. Zvláště u rozsáhlejších vypořádání si předkladatelé šetří práci a do tabulky někdy zařazují pouze zásadní připomínky, což samozřejmě významně limituje náš přehled o připomínkách ostatních (doporučujících). Upozornit je nutné na nedostatky v databázi eKLEP, některé soubory v systému chybí nebo nejdou otevřít. V neposlední řadě platí, že vzhledem k mimořádné náročnosti ručního zpracování takto komplexního souboru dat přes veškeré snahy o ex post kontrolu mohlo dojít k chybám či nepozornostem při kódování nebo zápisu dat. Zmíněné skutečnosti nemají však dle mého významný dopad na celkové výsledky - mezery v datech jsou ve srovnání s jejich celkovým shromážděným objemem zanedbatelné a hlavně jsou v populaci rozmístěné náhodně. Bude k nim nicméně i tak dále přihlédnuto při interpretaci některých závěrů.

$59 \mathrm{Na}$ zpracování datasetu se výraznou měrou podíleli Jakub Lysek z Filosofické fakulty Univerzity Palackého v Olomouci a Jaroslav Bílek z Filosofické fakulty Univerzity v Hradci Králové.

60 Ze souboru byly vyloučeny návrhy projednávané za vlády Jiř́ho Rusnoka. Dataset obsahuje pouze návrhy předložené do konce roku 2016, počet návrhů předložených do MPŘ ve zbytku volebního období Sobotkovy vlády v roce 2017 byl minimální. Zároveň byl výběr zúžen pouze na návrhy zákonů předložených ministerstvy. 
Data z MPŘ v „empirických“ sekcích článku budou prezentována výhradně ve formě popisných statistik a jednoduchých korelací. Důvody k tomu jsou dva. Text cílí svým obsahem i publikací v Časopise pro právní vědu a praxi primárně na právnickou obec a ta, přiznejme si, nepatří $\mathrm{k}$ velkým obdivovatelům komplikovanějších statistických modelů. Především ale použití inferenční statistiky, zkoumající tradičně dopad určité skutečnosti (nezávislá proměnná) na jinou skutečnost (závislá proměnná), nedává př́liš smysl. O MPŘ toho totiž dosud víme tak málo, že jsem nedokázal formulovat hlubší teorie k otestování.

\section{Přehled základních údajů o průběhu meziresortního připomínkového řízení a roli ministerstev $\mathrm{v}$ něm}

\subsection{Hlavní parametry meziresortního připomínkového řízení}

Připomínkování návrhů zákonů tvoří nedílnou součást činnosti řady subjektů veřejné správy a samosprávy. Ve sledovaném období bylo podáno ke zpracovaným 541 předlohám celkem 54903 připomínek všeho druhu, na jeden návrh zákona tedy v průměru připadá zhruba 100 připomínek. Rozdělení je ovšem velmi nerovnoměrné, medián (případ rozdělující populaci návrhů na dvě stejné poloviny) dosahuje hodnoty 56. Jinak vyjádřeno, polovina návrhů zaznamenala méně než 56 připomínek (několik návrhů mimochodem dokonce žádné), naopak relativně malá skupina návrhů se stala cílem činorodé připomínkové aktivity. Rekordmanem v tomto směru byl na konci roku 2014 do MPŘ zaslaný Návrh zákona o vnitřním řízení a kontrole ve veřejné správě (PID KORN9R6PNTGM), ${ }^{61}$ ke kterému bylo zasláno 3233 připomínek, jejichž vypořádání si vyžádalo 1203 stran závěrečné vypořádací tabulky. Dalších deset návrhů zákonů zaznamenalo více než 500 připomínek.

Rozdělení připomínkových míst do skupin (Tabulka 1) naznačuje výraznou převahu ministerstev (více $\mathrm{k}$ nim podkapitola níže). Přes někdy pocit’ovanou skepsi o míre zapojení krajů i ty zasílají relativně dost připomínek, byt' je pravdou, že soustředí své úsilí především na pár jich se týkajících návrhů, u kterých postupují koordinovaně. Větší kraje (Praha, Jihomoravský, Severomoravský) podávají připomínek mírně více. V pestré skupině zbylých povinných připomínkových míst panuje velká variabilita, ${ }^{62}$ nejaktivnějším subjektem byla Česká národní banka (cca 2400 připomínek), ze zástupců organizovaných zájmů pak Hospodářská komora (1 700 připomínek), Svaz průmyslu a obchodu (1 000) a Českomoravská komora odborových svazů (1 000). S právem v užším slova smyslu spojených institucí stojí za zmínku velmi omezený zájem vrcholných soudů (nejvíce Nejvyšší

61 PID značí identifikační číslo materiálu v systému eKLEP.

62 Připomínám diskreci předkladatele při oslovování těchto subjektů. Malé zapojení některých míst tudíž může být kromě vlastní pasivity zpo̊sobeno klidně i tím, že subjekt není do MPŘ zván. 
správní soud 134 připomínek) oproti třeba ombudsmanovi (650) nebo Úřadu na ochranu osobních údajů (950).

Tabulka 1: Rozvržení připomínek dle původce (povinná připomínková místa)

\begin{tabular}{|l|c|c|c|c|}
\hline & Ministerstva & Kraje včetně Prahy & $\begin{array}{c}\text { Ostatní povinná } \\
\text { pŕipomínková místa }\end{array}$ & Celkem \\
\hline Připomínek celkem & 33829 & 11747 & 9327 & 54903 \\
\hline Procentuální podíl & $62 \%$ & $21 \%$ & $17 \%$ & $100 \%$ \\
\hline
\end{tabular}

Zdroj: Autor na základě dat shromážděných J. Lyskem, J. Bílkem a R. Zbíralem.

Zkoumání vztahů mezi charakteristikou návrhu zákona a počtem připomínek ztěžuje nedostatek proměnných, které by návrhy v počátečním stadiu legislativního procesu mezi sebou odlišovaly. Smysl mi dávají tři v datech sledované faktory: zda návrh je novelou zákona nebo jde o nový zákon, zda návrh většinově implementuje právo EU a zda byl podán za Nečasovy nebo Sobotkovy vlády. Výsledky v počtu připomínek na návrh prezentuje Tabulka 2 (mediány mají s ohledem na velký rozptyl dat větší vypovídací schopnost). Hodnoty nicméně může ovlivňovat ještě jedna proměnná, totiž délka návrhu. Ukazuje se ne zcela překvapivě, že čím více slov návrh má, tím více připomínek k němu směřje. ${ }^{63}$ Proto $\mathrm{v}$ dalších sloupcích Tabulky 2 uvádím uvedené faktory přepočtené na počet slov návrhu na jednu připomínku, ${ }^{64}$ což umožňuje délku návrhu zohlednit.

Tabulka 2: Vztah mezi charakteristikou návrhu a počtem připomínek

\begin{tabular}{|l|l|c|c|c|c|}
\hline \multicolumn{1}{|c|}{} & \multicolumn{2}{|c|}{ Připomínek na návrh } & \multicolumn{2}{c|}{$\begin{array}{c}\text { Slov návrhu } \\
\text { na připomínku }\end{array}$} \\
\hline \multirow{2}{*}{ Forma návrhu } & nový zákon & 155 & 80 & 152 & 66 \\
\cline { 2 - 7 } & novela & 84 & 49 & 123 & 64 \\
\hline Transpozice práva EU & ne & 90 & 52 & 125 & 58 \\
\hline & ano & 118 & 67 & 140 & 78 \\
\hline Vláda & Nečas & 95 & 56 & 152 & 74 \\
\hline & Sobotka & 105 & 61 & 109 & 58 \\
\hline
\end{tabular}

Zdroj: Autor na základě dat shromážděných J. Lyskem, J. Bílkem a R. Zbíralem.

63 Korelace mezi počtem slov (délka návrhu) a počtem připomínek dosahuje hodnoty 0.627 (statistická významnost na 0.01 hladině; Pearsonova korelace).

64 Např. u návrhu zákona s délkou 10000 slov a 100 připomínkami bude výsledná hodnota 100, s 200 připomínkami 50. Tj. čím menší hodnota, tím více návrh podléhal připomínkování. 
U formy návrhu bych očekával menší počet připomínek v případě novel zákonů. Novely jsou z podstaty méně přehledné, je nutné pracovat s původním zákonem a znát jeho obsah, jde často pouze o tematicky dílčí úpravy. ${ }^{65}$ Medián počtu připomínek novel je skutečně významně nižší než u nových (celých) zákonů, protože jsou ale novely průměrně o dost kratší, předmětný rozdíl při kontrole délky návrhů v podstatě zmizí. Odborné zázemí připomínkových míst v MPŘ se evidentně dokáže se zmíněnými znevýhodněními novel vyrovnat. U návrhů zákonů transponujících unijní právo předpokládám z mnoha důvodů nižší počet připomínek, menší „zájem“ o tento druh návrhů zákonů byl mimo jiné už potvrzen v legislativním procesu ve Sněmovně. ${ }^{66}$ Při nezohlednění délky návrhů zákonů jde $\mathrm{v}$ MPR vztah opačným směrem, s přihlédnutím k ní se karta obrací a neimplementační („domácí‘) návrhy se setkávají s vyšší pozorností připomínkujících subjektů. Konečně návrhy zákonů ministerstev Sobotkovy vlády byly připomínkovány (při kontrole délky) znatelně více. Zde se žádné bezprostřední vysvětlení nenabízí. Spekulovat by šlo např́klad o dopadu menší zkušenosti politického vedení ministerstev s prŕípravou návrhů (žádná strana vládní koalice se neúčastnila předchozí vlády) či snahou koaličních partnerů být vưči sobě asertivnější (spor ANO-ČSSD), dostupná data bohužel nedokážou podobné předpoklady potvrdit. ${ }^{67}$

Dále se zaměřím na délku trvání MPŘ, i když zde situaci nejsem schopen zachytit zcela vypovídajícím způsobem. Rozpětí trvání bylo totiž zaznamenáno prostřednictvím zaznamenání počátečního a konečného dne MPŘ a z údajů tak lze spočítat jen celkový počet všech dnů MPŘ, nikoliv je omezit na pracovní, ve kterých lhůtu uvádějí LPV. ${ }^{68}$ I bez toho můžeme odvodit, že ve zhruba $60 \%$ př́padů byla zvolena LPV standardně předpokládaná lhưta 20 pracovních dnů (reálně kalendářní měsíc). Ačkoliv LPV umožňují lhůtu předkladateli prodloužit, stalo se tak jen v $15 \%$ př́padů, a to povětšinou jen o pár dnů. V čele pelotonu je návrh s PID KORN8HUCEK22, který byl v létě 2011 v připomínkovém řízení dva měsíce, ostatní návrhy nepřesáhly 40 dnů (včetně volných dnů). Naopak zbývajících 25 \% řízení obdrželo výjimku dle čl. 76 LPV a došlo u nich ke zkrácení lhůty, cca polovina $z$ nich přitom netrvala ani deset dnů.

65 Obdobně k menšímu „významu“ novel DIXON, Ruth a Jonathan JONES. Mapping Mutations in Legislation: A Bioinformatics Approach. Parliamentary Affairs, 2019, č. 1, s. 37.

66 Podrobně ZBÍRAL, Robert. Comparing the intensity of scrutiny for 'domestic' and implementing bills: does transposition of EU law reduce political contestation in national parliaments? Journal of European Public Policy, 2017, č. 7, s. 969-988. DOI https://doi.org/10.1080/13501763.2016.1170873

67 Tyto úvahy otevírají mnohem širší otázku, nakolik se v připomínkovém řízení vůbec promítají pohledy ministrů a jiných politických subjektů. Jelikož návrhy zákonů samozrejmě jsou vedeny politickými zájmy, lze předpokládat, že ani MPŘ není čistě úřednickým cvičením, o čemž ostatně svědčí i samotné znění rady připomínek - otevřeně je často při připomínkování a hlavně vypořádání uváděno, že předmětná záležitost je vedena politickým zadáním. Jak již ale bylo řečeno, dostupná data míru zapojení politiky do MPŘ postihnout nedokáží.

68 Rozdíl mezi dny je vypočítán jako prostý rozdíl dvou dat, funkce v tabulkovém editoru nerozpozná, které dny v daném rozmezí jsou pracovní. 


\subsection{Analýza působení ministerstev v meziresortním připomínkovém řízení}

Hodnoty prezentované v Tabulce 1 potvrzují zásadní úlohu ministerstev při připomínkování návrhů zákonů. Stejně tak samozřejmě ministerstva dominují při předkládání návrhů. Obojí prìrozeně plyne z jejich ústavně i zákonně daného postavení. ${ }^{69}$ Jak již bylo řečeno, specifickou pozici ministerstev uznávají rovněž LPV a garantují jim bezpodmínečné právo účastnit se všech MPŘ. Neomezený př́stup je zaručen rovněž Odboru kompatibility Úřadu vlády, jehož úkolem je posoudit návrh zákona z hlediska slučitelnosti s právem EU. Důležitost těchto subjektů i všeobecná př́istupnost s nimi souvisejících dat volají po bližším seznámení se s jejich působením v MPŘ.

Nejprve pozornost zaměřím na formu připomínek, u ministerstev jsme totiž též zaznamenávali, zda připomínka byla označena za důležitou, či nikoliv (doporučujícî). Z téměř 34 tisíc zaznamenaných připomínek jich 56 \% ministerstva považovala za zásadní. I když procentuální podíl nemusí být přesným obrazem reality, ${ }^{70}$ vysoký absolutní počet podstatných připomínek dosvědčuje, že jejich použití je v zásadě standardem a není vyhrazeno pouze k vymezení „červených liniî“. Ostatně nesystematičnost v pojetí zásadních připomínek plyne z odlišné praxe přpomínkových míst, zatímco ministerstvo zdravotnictví nebo Odbor kompatibility za zásadní označí kolem 70 \% jejich připomínek, u ministerstva kultury to je jen 28 \% a i u řady jiných subjektů tvoří zásadní připomínky menšinu.

Velmi nerovnoměrné je také rozložení připomínek mezi ministerstva, $\mathrm{v}$ tomto případě ale rozdíly smysl dávají a mohou být poměrně lehce vysvětleny. Primát nejčastěji př́ipomínkujícího místa pevně držící ministerstvo vnitra zastává nezastupitelné postavení a odpovědnost v systému organizace a výkonu veřejné správy, ${ }^{71}$ přičemž skoro všechny návrhy zákonů se nějakým způsobem veřejné správy přirozeně dotýkají. Obdobně zapojení ministerstva financí nesporně souvisí s dopady většiny návrhů na státní rozpočet či obecně ekonomiku. Bronzový Odbor kompatibility se soustředí na otázky slučitelnosti s právem EU, takřka 70 \% z jeho připomínek se vztahuje k návrhům implementujících unijní právo. Ministerstva na druhém konci žebříčku naopak patří k menším úřadům s úzkým polem věcné působnosti.

69 Za všechny srov. \ 24 zákona č. 2/1969 Sb., kompetenční zákon, ve znění pozdějších předpisů.

70 Připomínám, že ve vypořádacích tabulkách někdy nejsou doporučující připomínky zařazeny, takže jejich reálný počet bude vyšší.

71 Srv. \ 12 odst. 3 zákona č. 2/1969 Sb., kompetenční zákon, ve znění pozdějších předpisů. 
Graf 1: Počet připomínek podaných ministerstvy k návrhům zákonů

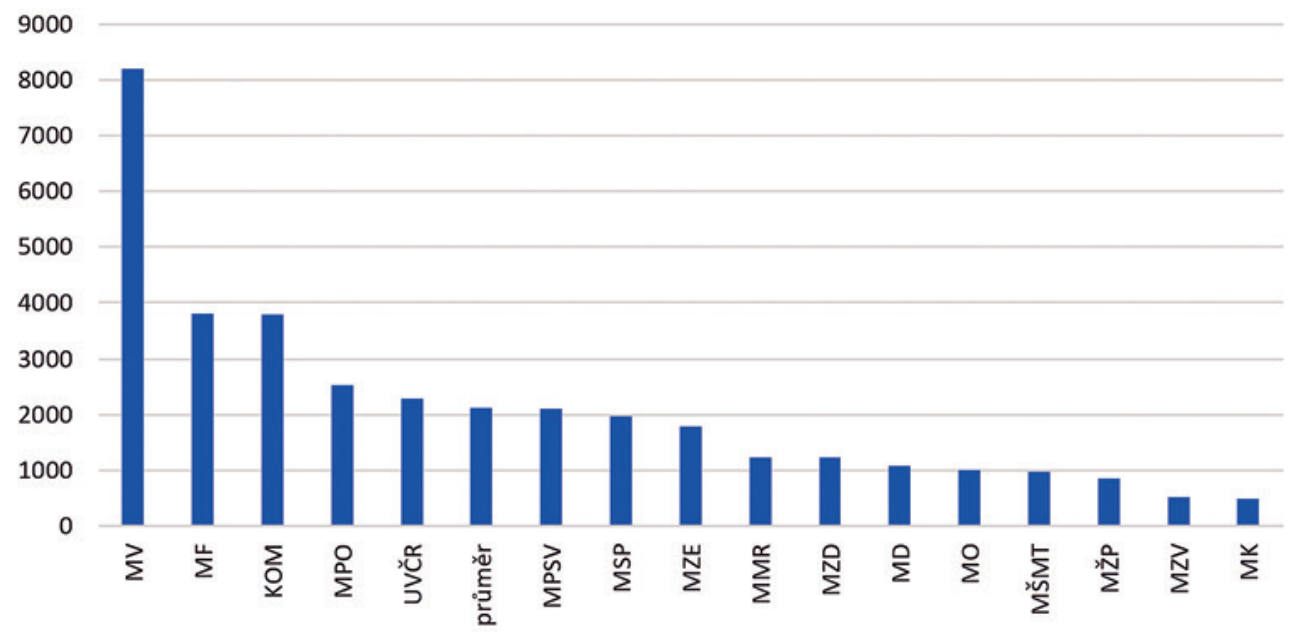

Zdroj: Autor na základě dat shromážděných J. Lyskem, J. Bílkem a R. Zbíralem.

Zaměřme se nyní na situaci z opačného pohledu. Jak si stojí ministerstva v MPŘ v pozici předkladatelů? Výsledky představuje Tabulka $3^{72}$ a opět naznačuje velký rozptyl mezi subjekty. Zdaleka nejvyšší počet připomínek obdrželo ministerstvo financí, poté se ministerstva dělí zhruba do dvou dalších skupin. O předkladatelích nicméně celkové hodnoty vypovídají málo, nebot' ministerstva připravují dosti rozdílné počty návrhů zákonů. Při přepočtu objemu připomínek na jednotlivý návrh se situace vyrovná, i tak platí, že třeba průměrný návrh ministerstva spravedlnosti nebo obrany je cílem připomínkování několikrát méně než předlohy ministerstva pro místní rozvoj, školství či financí. Další posun přinese zohlednění délky návrhů (k metodě srov. výše). Ve „vedeni““ zůstává ministerstvo spravedlnosti, přidává se k němu ministerstvo vnitra a ministerstvo dopravy. V př́ípadě prvních dvou subjektů by situaci mohl vysvětlovat „,právní" charakter jejich návrhů, který nemusí ostatní „věcná“ ministerstva tolik zajímat. Na druhou stranu „techničnost“" obsahu zdá se vliv př́liš nemá, např́klad ministerstva zdravotnictví a průmyslu a obchodu jsou obě odpovědná za úzce oborové předlohy a přitom se počty obdržených připomínek mezi nimi značně liší.

72 Z analýzy byly vyloučeny Odbor kompatibility (nepředkládá návrhy zákonů) a ministerstvo zahraničí (podalo ve sledovaném období pouze jeden). 
Tabulka 3: Počet připomínek obdržených ministerstvy v MPŘ k navrženým zákonům

\begin{tabular}{|c|c|c|c|c|c|c|}
\hline & \multirow{2}{*}{$\begin{array}{c}\text { Počet } \\
\text { předložených } \\
\text { návrhů }\end{array}$} & \multirow[t]{2}{*}{$\begin{array}{l}\text { Připomínek } \\
\text { celkem }\end{array}$} & \multicolumn{2}{|c|}{ Připomínek na návrh } & \multicolumn{2}{|c|}{$\begin{array}{l}\text { Počet slov návrhu } \\
\text { na připomínku }\end{array}$} \\
\hline & & & Průměr & Medián & Průměr & Medián \\
\hline MF & 117 & 15653 & 134 & 74 & 83 & 62 \\
\hline MV & 55 & 4647 & 84 & 54 & 202 & 110 \\
\hline MPSV & 50 & 4266 & 85 & 50 & 95 & 74 \\
\hline MŽP & 31 & 4258 & 137 & 72 & 110 & 49 \\
\hline MSP & 72 & 4247 & 59 & 24 & 299 & 141 \\
\hline MMR & 24 & 4115 & 179 & 80 & 106 & 55 \\
\hline MZE & 34 & 3610 & 106 & 84 & 58 & 53 \\
\hline MPO & 46 & 3585 & 78 & 46 & 63 & 35 \\
\hline MZD & 36 & 3231 & 90 & 59 & 136 & 85 \\
\hline MŠMT & 14 & 1517 & 108 & 91 & 80 & 28 \\
\hline ÚVČR & 18 & 1472 & 82 & 53 & 64 & 15 \\
\hline $\mathrm{MD}$ & 19 & 1423 & 75 & 64 & 203 & 104 \\
\hline MK & 12 & 1358 & 113 & 91 & 58 & 46 \\
\hline $\mathrm{MO}$ & 13 & 671 & 52 & 37 & 83 & 49 \\
\hline
\end{tabular}

Zdroj: Autor na základě dat shromážděných J. Lyskem, J. Bílkem a R. Zbíralem.

Nabízí se otázka, zda mezi určitými ministerstvy nefungují nějaké „privilegované“ vazby a nepřipomínkují si z různých důvodů návrhy mezi sebou více nebo méně, než bychom očekávali. Poskytnutí přesvědčivé odpovědi je při počtu interakcí mezi subjekty a objektivním rozdílům $\mathrm{v}$ počtech připomínek takřka nemožné. Alespoň přibližně vzájemné vztahy umožňuje odhalit vizualizace v Grafu 2. Žádné mimořádnosti z ní nevyplývají, všechna připomínková místa se nediskriminačně připomínkují navzájem. 
Graf 2: Vzájemné interakce mezi ministerstvy jako předkladateli (levá strana) a připomínkovými místy (pravá strana). Započteny byly pouze zásadní připomínky.

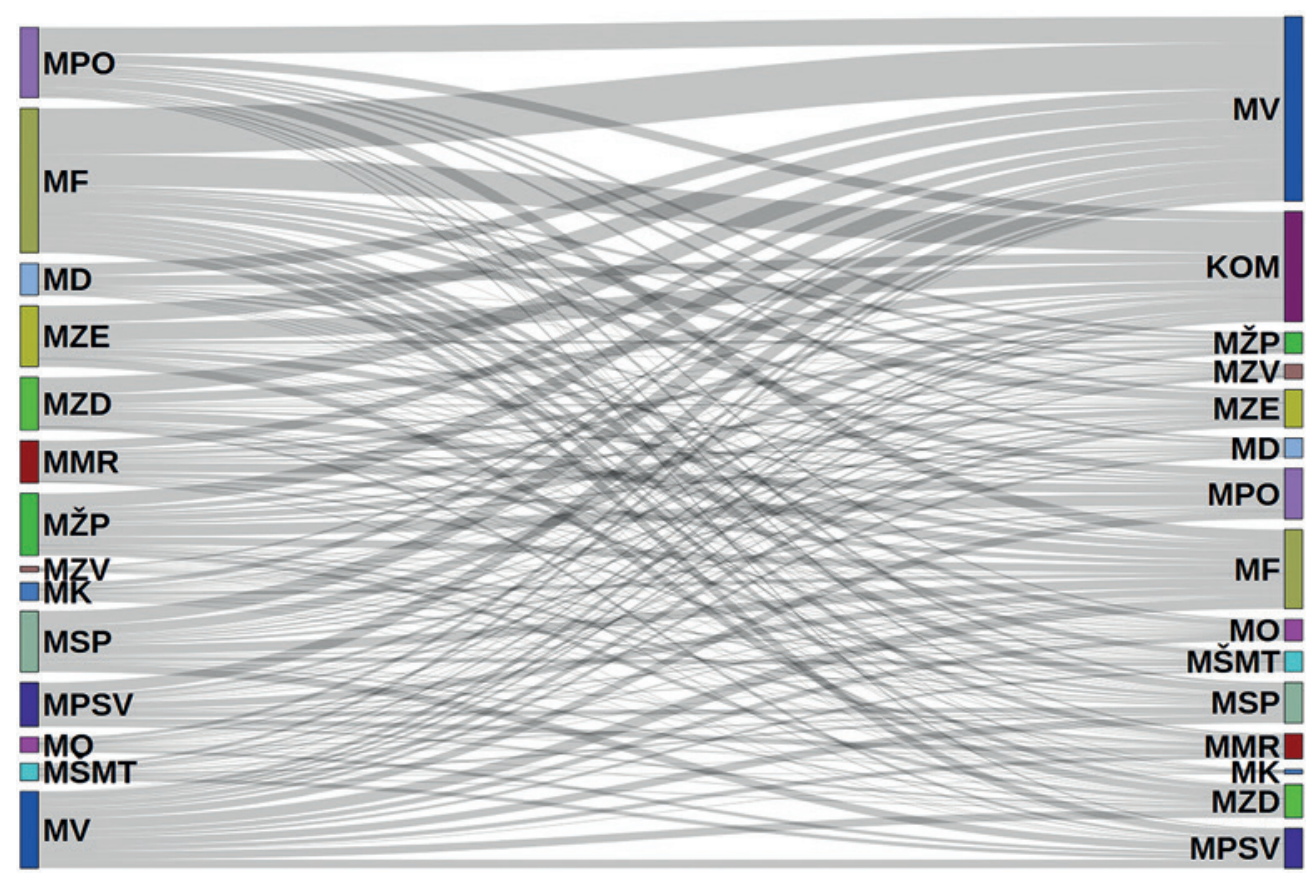

Zdroj: Michal Škop (KohoVolit.eu) na základě dat shromážděných J. Lyskem, J. Bílkem a R. Zbíralem.

\section{Dopad meziresortního připomínkového řízení na podobu návrhů zákonů}

Provedená analýza podoby a praktického průběhu MPŘ nám prozradí mnohé, jen málo z ní nicméně odvodíme, nakolik je vlastně MPŘ efektivní a užitečné. Kolektiv autorů kolem Martina Škopa v tomto směru např́iklad návodně žádá: „[...] bylo by relevantni zjïstit, nakolik jsou prïpominky jednotlivých mist (včetně soudui) prínosné, či nakolik se soustredi pouze na podružnosti. "73 Předmětná publikace odpověd' na otázku systematicky nepodává, ${ }^{74}$ do jisté míry tak činí ovšem jiné. Bartošek se např́klad domnívá, že většina připomínek k návrhům zákonů je formálně-legislativního rázu, MPŘ se zaobírá malichernostmi a věcná diskuze je potlačena. ${ }^{75}$ Velmi kriticky se $\mathrm{k}$ dopadům MPŘ vyjadřují nezávisle

73 ŠKOP a kol., 2019, op. cit., s. 34.

74 Neodpustím si upozornění, že položená otázka ukazuje na výše poukazovanou důležitost ohledání reálného stavu věcí prostřednictvím dat. Z těch z MPŘ lze totiž zjistit již uvedenou skutečnost, že soudy připomínkují návrhy zákonů zcela minimálně a otázka se jich tak vlastně netýká.

75 BARTOŠEK, 2014, op. cit., s. 34. 
na sobě také Kysela a Šín, vyčítají mu roztř́íštěnost, nedostatečnou spolupráci a součinnost připomínkových míst, která se soustředí pouze na obhajobu svých partikulárních problémů (resortismus). ${ }^{76}$

Potíž podobných úvah o hodnocení tkví dle mého v tom, že nepanuje shoda, k čemu by MPŘ vlastně ve vztahu $\mathrm{k}$ návrhům zákonů mělo primárně sloužit. Pokud začneme na makroúrovni, opravdu má jít o řízení, ve kterém dochází k výměně názorů na podobu v návrhu definovaných hlavních cílů/řešení a jehož účelem je klidně úplně změnit obsah návrhu? Nebo by měla být raději respektována licence předkladatele, za níž nese politickou odpovědnost, a MP̌̌ využíváno spíše k „dočištěni““ podoby návrhu a odstranění právních a obsahových nedostatkư? ${ }^{77}$ Má být každé připomínkové místo „generalistou“ a vyjadřovat se ke všemu, či se pouze soustředit na oblast, za kterou odpovídá a zbylé věci nechat na ostatních? Konečně při přesunu na mikroúroveň - jak poznáme připomínku formální, podružnou, přínosnou? Přestože jsou podobné otázky legitimní a má cenu nad nimi uvažovat, domnívám se, že odpověd’ na ně bude vždy tak trochu „záležet na situaci“ a různých vnitřních a vnějších podmínkách. Jiné bude asi očekávání a poté i průběh u MPŘ návrhu zákona transponujícího technické požadavky směrnice $\mathrm{X}$ o hnojivech ve srovnání s MPŘ návrhu zavádějícího školné na vysokých školách bez předchozí domluvy s kýmkoliv. Obdobně ani připomínka upozorňující na mezi legislativci legendární „chybějící čárku“ nemusí být bezobsažnou formalitou. ${ }^{78}$ Ve zbytku kapitoly proto z těchto důvodů odpovídám pouze na otázku, jaký dopad MPŘ má na podobu návrhů zákonů. Naopak nemám ambici tyto dopady nějak normativně hodnotit.

Nejvýrazněji MPŘ zasáhne do osudu návrhu zákonu bezpochyby tehdy, když mu zazvoní př́slovečný umíráček. Pokud předkladatel z reakce připomínkových míst sezná, že navržená podoba návrhu čelí širokému odporu bez možnosti jeho zlomení nějakými úpravami předlohy, je stažení návrhu veskrze racionálním rozhodnutím. Jak bylo už uvedeno, z 623 zpracovaných návrhů v 82 prrípadech (13\%) předkladatel po dokončení MPŘ ani neprováděl vypořádání připomínek. Největší podíl takových neúspěšných návrhů si připsala ministerstva vnitra, školství a Úřad vlády (kolem 20 \% ze všech jimi předložených), na druhém konci žebříčku pouze ministerstvo obrany nezaznamenalo ani jeden. Z hlediska charakteristiky spadají tyto návrhy zákonů do dvou skupin. Jednu tvoří předlohy, u kterých předkladatel zdá se ani schválení neočekává: sem patří rưzné pokusné balónky, někdy až skoro bizarnosti, které mají maximálně (nejasnou) politickou hodnotu. ${ }^{79}$ Druhá

76 ŠÍN, 2009, op. cit., s. 92-93; GERLOCH a kol., 2009, op. cit., s. 202-203.

77 Druhá varianta není myšlena jako kvalitativně méněcenná k první, odstranění nedostatků má zásadně pozitivní dopad.

78 Aneb čárka dokáže být otázkou života a smrti, jak připomíná neslavně proslulý údajný telegram Stalina Berijovi a rozdíl mezi „Popravit, nelze propustit.“ a „Popravit nelze, propustit.“

79 Př́kladem budiž návrh ministerstva pro místní rozvoj z roku 2016 znárodňující areál Pražského hradu (PID KORNA9UBV32F). 
skupina se skládá z vážně míněných návrhů, u nichž však připomínky poukázaly na předkladatelem nezamýšlené důsledky či nedostatky, potažmo bylo poukázáno na možnost jiného, efektivnějšího řešení problému. Mám za to, že v obou těchto situacích MPŘ efektivně plní svou úlohu a v rozporu s výše uvedenými kritickými vhledy není jen přehlídkou malicherných námitek.

Obecným záměrem MPŘ a všech zúčastněných subjektů jistě je přispět k vylepšení předložených návrhů zákonů. Jestli k tomu dochází, můžeme do jisté míry odvodit ze způsobu vypořádání připomínek. Tabulka 4 představuje údaje o formě vypořádání zásadních prripomínek prrijatých a podaných ministerstvy. Výsledky potvrzují, že připomínky jsou většinově plně akceptovány a tedy promítnuty do textu návrhů, naopak jen zhruba desetinu připomínek překladatelé (bez rozporu) odmítají. Vysoká míra vzájemného vyhovění svědčí o pozitivních dopadech MPŘ.

Tabulka 4: Způsob vypořádání zásadních připomínek ministerstev ( $\mathrm{v} \%$ )

\begin{tabular}{|c|c|c|c|c|c|c|}
\hline & \multicolumn{3}{|c|}{ Subjekt jako připomínkové místo } & \multicolumn{3}{|c|}{ Subjekt jako předkladatel } \\
\hline & Vyhověno & Vysvětleno & Neakceptováno & Vyhověno & Vysvětleno & Neakceptováno \\
\hline $\mathrm{KOM}$ & 70 & 24 & 5 & & & \\
\hline MV & 72 & 19 & 9 & 57 & 33 & 10 \\
\hline $\mathrm{MZV}$ & 57 & 32 & 10 & & & \\
\hline MZD & 58 & 31 & 10 & 67 & 16 & 17 \\
\hline MF & 67 & 21 & 12 & 60 & 26 & 14 \\
\hline MPO & 60 & 28 & 13 & 72 & 24 & 4 \\
\hline MMR & 52 & 31 & 15 & 55 & 26 & 19 \\
\hline MPSV & 60 & 24 & 15 & 55 & 29 & 16 \\
\hline MSP & 69 & 16 & 15 & 57 & 24 & 19 \\
\hline MZE & 49 & 36 & 16 & 79 & 15 & 6 \\
\hline MK & 59 & 24 & 16 & 68 & 24 & 8 \\
\hline MZP & 55 & 29 & 17 & 61 & 34 & 5 \\
\hline $\mathrm{MD}$ & 54 & 29 & 17 & 74 & 20 & 6 \\
\hline MO & 54 & 27 & 19 & 83 & 11 & 6 \\
\hline UVČR & 49 & 32 & 19 & 75 & 11 & 14 \\
\hline MŠMT & 48 & 26 & 26 & 66 & 25 & 10 \\
\hline Celkem & 63 & 25 & 12 & 63 & 25 & 12 \\
\hline
\end{tabular}

Zdroj: Autor na základě dat shromážděných J. Lyskem, J. Bílkem a R. Zbíralem. 
Přestože připomínky ministerstev jsou většinově akceptovány, nelze přehlédnout značné rozdíly v míře (ne)úspěšnosti mezi nimi. Platí zde statistický vztah, že čím více připomínek subjekt podává, tím nižší je šance, že jeho připomínka bude odmítnuta. ${ }^{80}$ Př́íkladnými zástupci předpokladu jsou Odbor kompatibility a ministerstvo vnitra, od kterých pochází nejvíce zásadních připomínek a vymykají se rovněž v úspěšnosti. Obtížnější je odhalení kauzality: vychází úspěch obou subjektů z dovedností a zkušeností získaných přpomínkovací praxí, nebo je navázán spíše na jejich specifické postavení v systému státní správy? $\mathrm{V}$ prrípadě Odboru kompatibility má předkladatel vysokou motivaci neodmítat připomínky tohoto specializovaného odborného subjektu, protože dle čl. 17 Metodických pokynů $^{81}$ je vládě v zásadě možné předložit pouze návrhy plně slučitelné s právem EU. Pozice Odboru kompatibility je následně zvýrazněna jeho propojením s Pracovní skupinou LRV pro evropské právo. ${ }^{82}$ Pro její jednání Odbor kompatibility prripravuje stanovisko, které upozorňuje na přetrvávající nedostatky ve slučitelnosti návrhu. Předkladatel tudíž ví, že nevyhověním v připomínkovém řízení se námitky nezbaví a bude se z ní zodpovídat na jednání citované pracovní skupiny. Za takových podmínek není neakceptování připomínek racionální strategií. Sice v méně procedurálně formalizované pozici než Odbor kompatibility u unijního práva, z ostatních hledisek ale obdobně výjimečnému postavení včetně navázání na pracovní skupiny LRV se těší ministerstvo vnitra ve vztahu k organizaci veřejné správy. Na chvostu žebříčku mírně zaostávají Úřad vlády a ministerstvo školství, zde coby vnější pozorovatel bezprostřední vysvětlení nenacházím. ${ }^{83}$ Totéž platí u posouzení výsledků ministerstev v roli předkladatelů. Větší ministerstva čelící vyššímu počtu připomínek (viz Tabulka 3) zdá se při vypořádání připomínek vystupují asertivněji, data nám ale neodhalí, zda to je z důvodu lépe připravených návrhů zákonů (připomínky ostatních pak objektivně nejsou oprávněné) nebo politické či byrokratické síly těchto předkladatelů (obhájí si nevyhovění i oprávněným připomínkám).

Z ochoty předkladatelů většinově akceptovat připomínky plyne, že návrhy zákonů se na základě MPŘ mění. Ve zbytku sekce se pokusím ukázat, do jaké míry. Zde opět čelíme již několikrát diskutovanému dilematu, jak přesně změnu vyjádřit. Právníkům není třeba detailně vysvětlovat, že rozsah změny nemusí odpovídat jejímu významu. I posun pouze v několika číslovkách (naprríklad u sazeb daně) nebo několik slov dlouhá

80 Míra korelace mezi počtem připomínek podaných připomínkovým místem a procentem mu neakceptovaných připomínek dosahuje hodnoty -0.52 (statistická významnost na 0.05 hladině; Pearsonova korelace).

81 Metodické pokyny pro zajišt’ování prací při plnění legislativních závazků vyplývajících z členství České republiky v Evropské unii, verze únor 2018. Dostupné z: https://www.vlada.cz/assets/jednani-vlady/ kompatibilita-s-pravem-es/Metodicke_pokyny_UZ.pdf

82 Ředitel a zástupkyně ředitele Odboru kompatibility jsou předsedou a místopředsedkyní pracovní skupiny. Považuji za férové uvést, že jsem členem této pracovní skupiny.

83 Může to souviset např́klad s velikostí legislativních odborů, které u těchto ministerstev budou menší a tvorba legislativy i prripomínkování pak více ovlivňují věcné odbory, $\mathrm{k}$ tomu srov. prímá svědectví v ŠKOP a kol., 2019, op. cit., s. 164-165. 
úprava měnící seznam oprávněných subjektů k podání opravného prostředku mohou mít zcela zásadní dopad. Vhodnou metodou k postihnutí podobných změn je názor odborníka - jestliže obsahu návrhu rozumí, dokáže posun umístit na nějaké škále (např. nulový až velmi vysoký) a třeba mu přiřadit i kvalitativní rozměr (pozitivní či negativní změna). Nevýhody metody jsou v podstatě dvě: bylo by extrémně náročné shánět odborníky na zhodnocení stovek zákonư ${ }^{84}$ a samotné posouzení bude nutně subjektivní (nízká reliabilita) a výsledky odborníků z různých právních odvětví těžko srovnatelné.

Proto považuji za vhodnější využít objektivních metod, snažících se míru proměny návrhů postihnout kvantitativně. $\mathrm{O}$ přesvědčivosti a efektivitě způsobu výpočtu změny zákonů se v odborné obci vedou bohaté diskuze. ${ }^{85} \mathrm{~V}$ tomto článku jsem použil simultánně dvě varianty. První jednoduše porovnává délku návrhu zákona před vstupem do MPŘ s délkou návrhu po MPŘ (tj. verzí návrhu do vlády) a vypočítává procentuální míru rozdílu mezi nimi. Metoda slušně zachytí př́ipady, kdy se návrhy rozšiřují nebo naopak zužují, nedokáže ale z podstaty rozeznat úpravy uvnitř samotného textu návrhu. K tomu je nutné pristoupit k sofistikovanějším řešením, konkrétně metodě vektorové počítačové analýzy textu. ${ }^{86}$ Spočívá velmi zjednodušeně v tom, že text je rozdělen na malé kousky (uni-gramy), u kterých je sledováno kromě obsahu také jejich umístění v textu. Počítač automaticky porovnává dvě verze návrhu a všechny relevantní změny mezi uni-gramy zachytí. U každého zákona je nakonec spočítán index změny, který pro přehlednost sahá od 0 (žádná změna) do 100 (oba dokumenty se naprosto odlišujî). ${ }^{87} \mathrm{Na}$ druhou stranu i u vektorové analýzy jako každé kvantitativní metody platí, že není schopna zohlednit důležitost změny, je v tomto ohledu „slepá“.

Míru změn návrhů zákonů po provedení MPŘ prezentuje Tabulka 5. Ačkoliv každá z použitých variant zachycuje změnu jinak a hodnoty u indexu změny (počítačové srovnánî) jsou celkově o něco nižší, v podstatě docházejí ke srovnatelným výsledkům. Návrhy zákonů se na základě MPŘ změní v průměru zhruba ze $20 \%$, což hodnotím jako změnu značnou. Platí to též ve srovnání s ostatními fázemi legislativního procesu, hodnoty indexu změny při projednávání návrhu ve vládě (včetně LRV) a parlamentu jsou v průměru nižší. ${ }^{88}$ Neplatí, že by hodně návrhů procházelo beze změn, podíl návrhů zákonů s indexem změny pod hodnotu indexu 5 je sotva pětinový. Na rozdíl od předchozích porovnání nezaznamenáváme ( snad až na ministerstvo kultury) velkých rozdílů

84 Jedna osoba, byt' i s právnickým vzděláním, nemá čas ani znalosti takové zhodnocení dobře provést.

85 Detailně včetně odkazů na zdroje nap̌r. DIXON, JONES, 2019, op. cit.

86 Inspirací (s modifikacemi pro češtinu) bylo řešení použité v GAVA, Roy a kol. Legislating or rubber-stamping? Assessing parliament's influence on law-making with text reuse. European Journal of Political Research, 2021, č. 1, s. 175-198.

87 Porovnání i výpočet probíhaly na základě skriptu, který vytvořil v programu R Vladimír Matlach z Katedry obecné lingvistiky Filosofické fakulty Univerzity Palackého. Sběr obou verzí návrhů zákonů a výpočty provedl Jakub Lysek.

88 Data jsou k dispozici na vyžádání na robert.zbiral@law.muni.cz 
ani mezi ministerstvy $\mathrm{v}$ pozici předkladatelů, hodnoty se pohybují kolem průměru. Zároveň vykazuje každé ministerstvo široký rozptyl mezi nejméně a nejvíce změněnými návrhy zákonů. V neposlední řadě analýza potvrzuje, že změny v návrzích zákonů majî návaznost na průběh MP̌̌, neboli čím více připomínek je podáno, tím více předkladatelé upravují text návrhů. ${ }^{89}$

Tabulka 5: Míra změny návrhů zákonů na základě MPŘ (dle předkladatele)

\begin{tabular}{|c|c|c|c|c|}
\hline & $\begin{array}{l}\text { Změna v délce } \\
\text { návrhu v \% } \\
\text { (průměr) }\end{array}$ & $\begin{array}{l}\text { Index změny } \\
\text { (průměr) }\end{array}$ & $\begin{array}{l}\text { Index změny } \\
\text { (minimum) }\end{array}$ & $\begin{array}{l}\text { Index změny } \\
\text { (maximum) }\end{array}$ \\
\hline MPO & 29 & 20 & 2 & 81 \\
\hline MZE & 29 & 19 & 1 & 45 \\
\hline ÚVČR & 19 & 18 & 3 & 45 \\
\hline MV & 30 & 18 & 0 & 73 \\
\hline $\mathrm{MO}$ & 24 & 18 & 0 & 58 \\
\hline $\mathrm{MŽP}$ & 24 & 18 & 2 & 73 \\
\hline MF & 25 & 17 & 0 & 72 \\
\hline MMR & 25 & 16 & 4 & 36 \\
\hline MŠMT & 30 & 16 & 8 & 30 \\
\hline MZD & 20 & 15 & 0 & 57 \\
\hline MD & 19 & 14 & 3 & 52 \\
\hline MSP & 20 & 14 & 1 & 44 \\
\hline MPSV & 22 & 14 & 0 & 87 \\
\hline MK & 10 & 9 & 0 & 22 \\
\hline Průměr & 24 & 17 & & \\
\hline Medián & 14 & 13 & & \\
\hline
\end{tabular}

Zdroj: Autor na základě dat shromážděných J. Lyskem, J. Bílkem a R. Zbíralem.

\section{Závěr a návrhy na změny $\mathrm{v}$ organizaci meziresortního př́ipomínkového řízení}

Cílem článku bylo podrobně představit a analyzovat strukturu, průběh a výsledky MPŘ, včetně poskytnutí dat z praktického fungování procesu. Česká verze MPŘ je ve srovnání

89 Míra korelace mezi počtem připomínek v MPŘ a indexem změny je 0,128 (statistická významnost na 0.01 hladině; Spearmanova korelace). 
s okolními státy vysoce formalizovaný a sofistikovaný príklad konzultací návrhů právních aktů subjekty veřejné moci v exekutivní fázi normotvorby. Prochází jím fakticky všechny návrhy zákonů předložené ministerstvy a jinými správními orgány a má relativně pevný rámec, který dovoluje návrhy připomínkovat širokému spektru subjektů, předkladatel má povinnost připomínky vypořádat. Jednoznačnou pochvalu si zaslouží transparentnost MPŘ, připomínky včetně způsobu jejich vypořádání jsou volně př́istupné na internetu. ${ }^{90}$ Data získaná z populace návrhů prošlých MPŘ mezi lety 2010 až 2016 dokazují, že jde o využívaný nástroj legislativního procesu a většina návrhư čelí značnému množství připomínek, některé předlohy dokonce extrémně vysokému. Ačkoliv se do MPŘ aktivně zapojují všechny v LPV předvídané „,povinné“ subjekty, $\mathrm{v}$ obecné rovině $\mathrm{v}$ rolích předkladatelů i připomínkových míst dominantně působí ministerstva. Z hlediska míry zapojení do MPŘ mezi nimi sice panují rozdíly, ty jsou nicméně většinou objektivního rázu a tudíž dobře vysvětlitelné věcnou působností a charakterem jednotlivých ministerstev. Přestože někteří praktici a odborníci vnímají efektivitu MPŘ dosti skepticky, má analýza toto hodnocení nesdílí. Zaprvé, nezanedbatelný počet návrhů se setká v MPŘ s takovým odporem, že jejich prosazení raději předkladatel vzdá. Zadruhé, u zbylých návrhů předkladatelé většinu připomínek při vypořádání akceptují, naopak podíl odmítnutých připomínek tvoří pouhou desetinu z celku. Obojí svědčí o tom, že připomínky považují za prospěšné a promítají je do textu návrhů. Zatřetí, provedené metody zachycující kvantitativně míru změny návrhů odhalují jejich značnou průměrnou proměnu (kolem 20 \%) bez ohledu na předkladatele. Celkově tak mám za to, že MPŘ v zásadě plní účel, ke kterému bylo zř́izeno.

Uvedené neznamená, že nevidím prostor ke zlepšením. První doporučení je čistě formálního rázu a směřuje $\mathrm{k}$ větši standardizaci realizace MPŘ. Bylo by vhodné, pokud by připomínková místa co nejvíce sladila formu zasílaných připomínek, ideálně tak činila prostřednictvím přehledné tabulky, jasně oddělující jednotlivé připomínky a rozlišující je na obecné/k jednotlivým ustanovením a zásadní/doporučující. Obdobnou unifikací by měly poté projít rovněž vypořádací tabulky. Bohužel jsem nebyl schopen zjistit, jestli může $\mathrm{v}$ tomto směru přinést pokrok již přes deset let zaváděný (a neustále odkládaný) projekt e-Legislativa, ${ }^{91}$ nebot' z dostupných zdrojů neplyne, zda má zahrnovat též MPŔ. Aniž bych viděl do technických parametrů e-Legislativy, teoreticky by nemělo být nijak složité umožnit připomínky zpracovávat přímo do elektronických šablon návrhů, což by poté dovolilo snadné filtrování připomínek podle ustanovení, předkladatelů atd. Všichni zúčastnění by již nemuseli neefektivně pracovat z rozsáhlými nepropojenými textovými soubory (navíc každý v jiné formě), ale jednotným databázovým prostředím.

90 Toto ocenil mj. i nález Ústavního soudu ze dne 18. 12. 2018, sp. zn. Pl. ÚS 4/18, bod 43.

91 K němu například STUPKA, Václav. E-Sbírka a e-Legislativa. Revue pro právo a technologie, 2014, č. 9, s. 185-196. 
Další doporučení se již váže na obsah MPŘ a týká se snížení míry diskrece předkladatelů ve výběru připomínkových míst. Nepokládám za správné, aby předkladatelé disponovali oprávněním selektovat mezi „neprivilegovanými“ povinnými připomínkovými místy. Všechny subjekty uvedené v LPV zastávají důležité veřejné či soukromé zájmy a nenacházím rozumného důvodu, proč by neměly být u nějakého návrhu zákona oslovovány. Stejný závěr ale lze dle mého rozšriríit i na subjekty mimo okruh předvídaný LPV, jejichž zapojení je nyní zcela v diskreci předkladatele. Proč by nemohly být automaticky zvány do MPŘ rovněž různé neziskové či zájmové organizace, které se na určitou problematiku specializují a mají k ní tedy co říci? Aby se zabránilo svévoli při výběru, šlo by to provést napríiklad tak, že by každé ministerstvo mělo vlastní seznam subjektů, které by muselo informovat o zahájení MP̌̌ „svých“ návrhů. O zařazení organizace na seznam ministerstva by mohla rozhodovat třeba LRV. ${ }^{92}$ Jak rúká populární prísloví, „více hlav ví více“ a větší počet prípomínek přece nemůže návrhu ubližit. Tato připomínková místa by neměla mít možnost rozporů a je samožrejmě otázkou do diskuze, jakým způsobem by jejich připomínky měly být vypořádány (postačí zveřejnění připomínek?, hromadné vypořádání?, komplexně jako s ostatními?). Naopak v zapojování veřejnosti pozitiva nevidím. Různorodé věcné zájmy jednotlivců či jejich skupin dokáží efektivněji zastoupit povinná připomínková místa a zejména specializované organizace, jejichž účast v MPŘ jsem právě doporučil. Dưležitá část veřejnosti - nezávislí právnî experti - mají většinou možnost vstoupit do legislativního procesu jako členové pracovních skupin či velké LRV.

Jak již bylo několikrát upozorněno, zásadním parametrem pro efektivitu MPŘ je čas. Kvalitní zvládnutí všech kroků je pro připomínková místa objektivně náročné (viz sekce o průběhu) a vyžaduje dostatečný časový prostor. Lze důvodně pochybovat, zda tak lze učinit ve standardních 20 pracovních dnech a zda by napríklad po vzoru Rakouska nebylo vhodnější lhůtu prodloužit na šest týdnů. Jestliže celá exekutivní fáze projednávání návrhů zákonů trvá v průměru 140 dnů (o dalších stovkách dnů parlamentní fáze nemluvě), považuji dvoutýdenní zpomalení legislativního procesu za cenu více než prijatelnou.

Na druhou stranu musíme počitat s realitou legislativního provozu a předpokládat, že čím komplexněǰší by byl průběh MPŘ, tím větší by byla motivace předkladatelů jej obcházet. Poslední doporučení, platné pro současnou i možnou budoucí úpravu MPŘ, proto navazuje na předchozí a zaměřuje se na udělování výjimek dle čl. 76 LPV. Zkracování již tak krátké obvyklé lhůty MPŘ pokládám za nepríijatelné, reálně nelze očekávat, že by za jeden nebo dva týdny byl někdo schopen návrh zákona užitečně odpruipomínkovat. Navíc se mi zdá, že v mnoha př́padech se jedná o svévolný postup předkladatele, jak se vyhnout standardnímu MPŘ, který nemá nic společného např́klad s objektivnî

92 Připomínám, že v méně promyšlené formě již dnes podobně funguje zmíněný seznam konzultujících míst pro RIA (DataKO). 
nutností projednávání návrhu uspíšit. ${ }^{93} \mathrm{U}$ některých předloh je totiž v eKLEPu uvedeno, kdy předkladatel požádal předsedu LRV dopisem o výjimku a většinou se tak kupodivu děje klidně i měsíce před započetím (zkráceného) MPŘ. Jestliže předkladatel „předvídá“ výjimku takto dopředu, jistě by byl schopen popohnat o pár dnů/týdnů přípravu návrhu v resortu a poté ušetřený čas využít na konání standardního MPŘ. Místo toho se dle mého názoru často koná „stínová hra“ - některá připomínková místa jsou kvưli výjimce vyloučena či z důvodu krátké lhůty připomínkování vzdají, jiným, předkladateli přívětivým, je návrh poskytnut neformálně dříve, a tak stihnou své připomínky přes šibeniční termín ,zázračně“ zaslat. Praxi výjimek je proto potřebné opustit, potažmo alespoň jejich udělení neponechávat na libovůli jediné osoby, ale např́klad jej podmínit souhlasem LRV, který by mohl být jistě v př́padě nezbytnosti dosažen i per rollam.

MPŘ samozřejmě zůstává pouze jedním (byt' důležitým!) z dílků složité skládačky tvorby právních předpisů v ČR. Jestliže do něj např́klad vstupují návrhy zákonů, u kterých není jasný ani jejich cíl či neexistuje základní shoda na způsobu legislativního nebo věcného řešení dané problematiky, nemůže takové nedostatky MPŘ ze své podstaty napravit. ${ }^{94}$ Stejně tak není vinou MPŘ, pokud se na jeho základě upravený návrh obsahově negativně změní v dalších fázích legislativního procesu. Popravdě i zdá se stále častější praxe předkládání zastřených ministerských návrhů pomocí poslaneckých iniciativ či pozměňovacích návrhů nakonec spíše osvědčuje reálně významný dopad exekutivní fáze včetně MP̌̌ - pokud by se v nich řešily malichernosti, nebyl by důvod je obcházet...

93 Shodně ČEBIŠOVÁ, Taisia. Politika, reformy a správní normotvorba. In: ŠTURMA, Pavel et al. (eds.). Nové jevy v právu na poćátku 21. století. Praha: Karolinum, 2009, s. 320.

$94 \mathrm{Na}$ okraj velmi kriticky podotýkám, že oproti zmíněným více než šesti stům návrhů zákonů bylo ve sledovaném období do MP̌̌ zasláno pouze 63 věcných záměrů zákonů. 